\title{
The sensitivity of North American mountain basin snow hydrology to changes in air temperature and precipitation
}

\author{
Kabir Rasouli ${ }^{1,2}$, John W Pomeroy ${ }^{1}$, and Paul H Whitfield ${ }^{1,3}$ \\ ${ }^{1}$ Centre for Hydrology, University of Saskatchewan \\ ${ }^{2}$ Faculty of Forestry, University of British Columbia \\ ${ }^{3}$ Environment and Climate Change Canada
}

April 28, 2021

The sensitivity of North American mountain basin snow hydrology to changes in air temperature and precipitation

Kabir Rasouli ${ }^{\mathrm{a}, \mathrm{b},}$ *, John W. Pomeroy ${ }^{\mathrm{a}}$, and Paul H. Whitfield ${ }^{\mathrm{a}, \mathrm{c}}$

${ }^{a}$ Centre for Hydrology, University of Saskatchewan, Canmore, AB, Canada

${ }^{\mathrm{b}}$ Faculty of Forestry, University of British Columbia, Vancouver, BC, Canada

${ }^{\mathrm{c} E n v i r o n m e n t}$ and Climate Change Canada, Vancouver, BC, Canada

\begin{abstract}
The hydrological sensitivity of snowmelt-dominated, high mountain headwaters to climate change was investigated using a physically based model to diagnose snow processes and headwater basin runoff response to perturbations of the current climate in three well-instrumented mountain research basins spanning the northern North American Cordillera. High-resolution hourly meteorological observations were perturbed using air temperature increases and precipitation changes and then used to force comprehensive, mountain hydrological models created using the modular, process-based Cold Regions Hydrological Modelling Platform (CRHM) for each basin. Simulations using multiple elevations show that both peak snowpack and annual runoff respond to warming and precipitation changes and these responses vary with latitude. In all three basins, the timing and magnitude of peak snowpack were sensitive to changes in temperature and precipitation, but timing was most sensitive to temperature. Annual runoff was far less sensitive to temperature than the snow regime. The impacts of the range of warming expected from North American climate model simulations on annual runoff, but not peak snowpack, can be offset by the size of precipitation increases projected for the future period 2041-2070. To offset the impact of $2^{\circ} \mathrm{C}$ warming on annual runoff, precipitation would need to increase by less than $5 \%$ in all three basins. To offset the impact of $2^{\circ} \mathrm{C}$ warming on peak snowpack, however, precipitation would need to increase by $12 \%$ in Wolf Creek - Yukon Territory, $18 \%$ in Marmot Creek - Canadian Rockies and an amount greater than the maximum projected at Reynolds Mountain Idaho. The role of increased precipitation as a compensator for the impact of warming on mountain snow hydrology is more effective at the high elevations and high latitudes. Increased precipitation leads to resilient and strongly coupled snow and hydrological regimes in cold regions and sensitive and weakly coupled regimes in the low elevations and temperate climate zones.
\end{abstract}

Keywords: Climate change, mountain hydrology, North American Cordillera, hydrological processes, cold regions, sensitivity analysis 
${ }^{*}$ Corresponding author. Email address: kabir.rasouli@ubc.ca

\section{Introduction}

How combinations of temperature increases and precipitation changes affect the magnitude and timing of peak snowpack and annual runoff in mountain basins is investigated in this sensitivity study. High elevation mountain headwater basins are hydrologically important, as they store water in the form of snowpack during winter and release it in spring and summer (Barry, 1992; Bales et al., 2006), and, ecologically important as they are key zones for biodiversity due to steep gradients of air temperature, precipitation, and topography (Beniston, 2003). Mountain snowpacks are sensitive to warming (Minder, 2010). Air temperature changes exert important controls on the hydrology of basins where snowmelt is the dominant hydrological process (Marks et al., 1998; Pederson et al., 2011; Sospedra-Alfonso et al., 2015). The contribution of mountain headwaters to the downstream discharge of rivers ranges from 35\% in cold and humid river basins to $90 \%$ in hot and arid basins (Viviroli and Weingartner, 2004). Mountains cover 25\% of the Earth's land surface (Diaz et al., 2003) and 26\% of the world population live in high-elevation areas (Meybeck et al., 2001). The origin of discharges from $50 \%$ of the world's rivers are mountain headwaters (Beniston, 2003). Snowmelt volume and timing play a key role in freshwater availability, flood control, and ecological sustainability of cold region mountain environments (Stewart et al., 2004; Semmens and Ramage, 2013).

The higher sensitivity of snow and frozen soils to warming makes cold region mountain basins, those with mean annual air temperatures near $0^{\circ} \mathrm{C}$, suitable study areas for investigating climate change impacts on the hydrological cycle (Barry, 1992; Bunbury and Gajewski, 2012). Climate warming effects have been studied in some mountain headwater basins (e.g., Cayan, 1996; Stewart et al., 2004; Bales et al., 2006), and warming is expected to continue to threaten the ecological and hydrological integrity of these regions (Malmqvist and Rundle, 2002). Fyfe and Flato (1999) showed that elevation becomes important to the pattern of climate change over western North America only when a significant continental-scale warming dominates, and it is not detectable in the early stages of climate change. Late winter and spring temperatures have a key role in the responsiveness of mountain basins to a warming climate and snowmelt runoff timing in regions with nearfreezing air temperatures (Stewart et al., 2004; McCabe and Clark, 2005; Rasouli et al., 2019a, 2020). Mote et al. (2005) reported that climatic trends and not changes in land use and forest canopy affect snowpack in western North America. A significant increasing temperature trend, especially in minimum temperature, led to a reduction in number of soil freeze days, earlier occurrence of plant-water stress, and a strong seasonal shift in streamflow throughout 1962-2006 in the high elevation Reynolds Creek Experimental Watershed, USA (Nayak, 2008).

A common approach for investigating the hydrological response to climate change is to apply climate model projections under different greenhouse gas emission scenarios and to downscale regional atmospheric circulations obtained from the climate models to variables at local scales using statistical or dynamical methods (e.g., Jasper et al., 2004; Fowler et al., 2007; McDonald et al., 2010). Mountain hydrometeorology, however, poses challenges to statistical and dynamical downscaling methods. The assumption in statistical downscaling that the predictor-predictand relationship is stationary and future relationships will be the same as past ones (Wilby and Wigley, 1997) does not guarantee that statistical downscaling approaches would perform better than the delta change method (Hay et al., 2000; Fowler et al., 2007; Kay et al., 2009; Sunyer et al., 2012). Dynamical models driven by an ensemble of multiple boundary conditions have high computational cost at the high resolutions needed in mountains and so usually neglect uncertainty and also require bias correction to provide reasonable forcings (Fang and Pomeroy, 2020). A realistic downscaling of atmospheric variables shows a high sensitivity to the choice of downscaling methods (Wilby et al., 2000). These limitations make consideration of an alternative solution necessary for mountainous regions.

As biases due to scale and parametrization issues have not yet resolved by statistical and dynamical downscaling methods, the alternative perturbation method also known as delta change factor method (e.g., Stockton and Boggess, 1979; Semadeni-Davies et al., 2008; Kawase et al., 2009), can produce plausible hydroclima- 
tological changes for the future. The perturbation method represents the changes in climatology between current and future climates for variables such as precipitation and air temperature (Stockton and Boggess, 1979; Pomeroy et al., 2015; Rasouli et al., 2019a, 2019b). The method retains the main hydrometeorological processes present in historical measurements, whilst minimizing computational resources. The perturbation method has been widely used; however, its application has been limited to air temperature changes factors (e.g., [?]T $=+-2 \operatorname{degC}$ in Nayak, 2008; Pomeroy et al., 2015) and precipitation change factors (e.g., [?]P = $+-25 \%$ in Lopez-Moreno et al., 2016).

The sensitivity of snow processes to warming were studied in the Canadian Rockies (Pomeroy et al., 2015) and Reynolds Creek, Idaho (Rasouli et al., 2015). The snow and runoff sensitivities to precipitation change and warming were studied in Wolf Creek, Yukon Territory (Rasouli et al., 2014). This sensitivity study applies similar sensitivity analyses to both snow and runoff regimes and in a comparable way for physically based cold regions hydrological models representing the three headwater basins that span much of the northern North American Cordillera. More specifically, this research investigates how the magnitude and timing of peak snowpack and annual runoff respond to combinations of temperature increases (0 to $5 \mathrm{degC}$ ) and precipitation changes $(-20,-10,0,+10$, and $+20 \%)$. By considering 30 combinations, applied to the three mountain headwater basins, the sensitivity of hydrological responses to changes in forcings can be compared. This increases the understanding of the relationships between changes in forcing and model response in these basins. The main question addressed is whether the impact of warming on mountain snow and runoff hydrology can be offset by precipitation increases. This has not been resolved in the literature (e.g., Arnell, 1999; Prowse et al., 2006, Luo et al., 2008). The specific objective for this sensitivity analysis is to quantify the response of simulated mountain hydrological processes to changes in air temperature and precipitation associated with future climate change.

\section{Data Sources}

Three instrumented headwater research basins located in the northern North American Cordillera are used to simulate potential hydrological responses to warming and precipitation changes; Wolf Creek, Yukon Territory, Canada; Marmot Creek, Alberta, Canada; and Reynolds Mountain East (hereafter Reynolds Mountain) catchment, Idaho, USA (Figure 1). The availability of long-term data from multiple hydrometeorological stations at different elevations in each basin, makes these basins uniquely suitable case studies for conducting sensitivity analysis on hydrological processes. High quality measurements of hourly air temperature, relative humidity, wind speed, incoming shortwave radiation, precipitation, and streamflow discharge for each basin were used. Consistent with the Ideal Gas Law, relative humidity was held constant to allow water vapour pressure to change with temperature. The forcing data are publically available (Wolf Creek: Rasouli et al., 2019c; Marmot Creek: Fang et al., 2019; Reynolds Mountain: Reba et al., 2011).

All three basins are snow-dominated under the current climate and are partially covered by coniferous forest at lower altitudes: Wolf Creek has spruce and pine forests, Marmot Creek has larch, fir, spruce, and pine forests; and Reynolds Mountain has fir, pine, and aspen forests. All elevations in Wolf Creek and the high elevations in Marmot Creek are very cold. A cold snow season with high precipitation leads to a long winter at high elevations in Marmot. High wind speeds in in the alpine zones of all three basins redistribute snow by wind transport and result in blowing snow sublimation losses. Needleleaf canopy snow interception and sublimation losses are important in all three basins. Air temperatures of the forested elevations in Wolf Creek are lower than for the alpine zone in winter, due to strong inversions in the Yukon River Valley. In contrast, Reynolds Mountain and low elevations in Marmot Creek have warmer air temperatures with fewer freezing days, making these more sensitive to warming. 


\section{Methods}

Snow and runoff regimes are simulated using models created with the Cold Regions Hydrological Modelling platform, CRHM (Pomeroy et al., 2007). These models were developed and evaluated with basin observations as per Fang et al. (2013), Rasouli et al. (2014, 2015) and Rasouli (2017), and then used to assess the sensitivity of the hydrological response to climate change in each of the three mountain basins by perturbing the model forcings.

The sensitivity experiments use the CRHM basin models, driven with perturbed forcings, to simulate outputs such as snowpack and coverage dynamics, and the timing and magnitude of runoff to capture the snow hydrological response to climate model outputs for the future. The sensitivities of interest are the hydrological responses to increases in air temperature and changes in precipitation that use the observed time series of air temperature and precipitation perturbed changes in the ranges projected by climate models under the Special Report on Emissions Scenarios (SRES) A2 (business-as-usual) and the Representative Concentration Pathways (RCPs) of global change for those basins. Rather than simulations based upon individual climate models, this linear sensitivity analysis provides an assessment of the scale of alteration of the hydrological cycle in mountain basins by climate change. This approach illustrates how the combination of changes in air temperature and precipitation might induce hydrological changes in these basins. Knowing how combinations of warming and precipitation changes induce future hydrological change in mountain basins from northern to mid-latitudes can be used to assess possible impacts of climate change.

\section{Climate Perturbation Sensitivity}

A climate perturbation sensitivity method is introduced here in which the current climate is perturbed based on projected future climatological changes. In this method, a climate perturbation signal of the future atmosphere is added to high-resolution baseline hourly observations. The general perturbation approach, and the method used here has two main assumptions: (i) GCM outputs for current and future climates show relative changes rather than absolute changes in climate; and (ii) the number of precipitation events is constant in current and future climates (Semadeni-Davies et al., 2008). The perturbation method used only modifies the observed past and does not consider future changes in frequency and intensity of weather patterns. The assumption of linear scaling used for temperature in the delta method may introduce uncertainties for nonlinear variables such as precipitation, particularly for extremes (Kay et al., 2009). It is also assumed that the basin vegetation, and in the case of Wolf Creek, permafrost (Williams et al., 2015), will remain unchanged.

The range of annual perturbations in precipitation and warming considered for this study is largely based on the atmospheric changes estimated by the SRES A2 scenario and two RCPs. The climate dataset used for the SRES A2 scenario was obtained from the North American Regional Climate Change Assessment Program (NARCCAP). These simulations provide climate data for regional climate models driven with GCM boundary conditions (Mearns et al., 2007). The range of temperature and precipitation perturbations was chosen based on the average climate changes that were obtained for RCPs and for the eleven NARCCAP regional climate models for the periods 2041-2070 minus 1971-2000. The climate dataset used for RCP scenarios was adapted from the recent Fifth Assessment Report of the Inter-governmental Panel on Climate Change (IPCC) (Barros et al., 2014). These four RCPs corresponding to specific radiative forcing values of $2.6,4.5,6.0$, and $8.5 \mathrm{~W} / \mathrm{m}^{2}$ were used as a basis for long-term and near-term modelling experiments in climate change studies. For the southern Yukon Territory (Wolf Creek) a warming of up to $2 \mathrm{degC}$ with an increase in the annual precipitation of less than $10 \%$, and a warming of up to $5 \mathrm{degC}$ with a $20 \%$ increase in annual precipitation are projected based on RCP2.6 and 8.5 respectively. Similar warming with smaller precipitation increases are expected in Marmot Creek and Reynolds Mountain. Most modelled scenarios project the future climate to be wetter, but some SRES scenarios (Moss et al., 2010) show regional decreases in precipitation of up to $15 \%$ for the 2080s. Rather than following any specific RCP or SRES, the sensitivity analysis spans potential changes in air temperature and precipitation from all RCP and SRESs; perturbing air temperature by $0 \operatorname{deg} \mathrm{C}$ to $5 \operatorname{deg} \mathrm{C}$ in $1 \operatorname{deg} \mathrm{C}$ intervals and precipitation by $-20 \%$ to $+20 \%$ in $10 \%$ intervals. These changes were applied to observations from all three basins. 
The degree of hydrological sensitivity to climatic changes is evident in the resulting shape and slope of contours of change in a variable (Figure 2). The contours were estimated by linear interpolation between the mean responses to the 30 combinations of warming ( $0 \mathrm{degC}$ to $5 \mathrm{degC}$ in intervals of $1 \mathrm{degC}$ ) and precipitation change $(-20 \%$ to $+20 \%$ in intervals of $10 \%)$. When a hydrological variable is more sensitive to air temperature increase or precipitation change, the contour line is perpendicular to that axis (Temperature Figure 2a; Precipitation Figure 2b), when the variable is sensitive to a linear interaction of air temperature and precipitation changes, there will be a slope in the contour line (Figure 2c), and if the interaction is complex, the slope and the contours will not be straight lines (Figure 2d). Applying the same ranges of change in air temperature and precipitation to each of the three basins allows direct comparison of the responses of the simulation model for each basin. Different combinations of warming and precipitation change make it possible to estimate how much additional precipitation is needed to offset the impacts of a specific air temperature increase on annual runoff and peak snowpack. The additional precipitation increases were estimated based on the interpolation of the two contour lines above and below the present climate values.

To compare and contrast snow accumulation and ablation amongst sites, hydrological response units (HRUs) in Wolf Creek are grouped into alpine, shrub tundra, and forest zones based on biomes and elevation bands; in Marmot Creek the HRU are grouped into alpine, treeline (affected by blowing snow from alpine), forest, and forest clearings; and in Reynolds Mountain the HRU are grouped into source, sink, interception, and sheltered snow regimes (Figure 1). The mean annual peak snow accumulation is defined as the average maximum snow water equivalent (SWE) over the hydrological year and occurs in March or April in these basins.

The probability density function (PDF) of simulated hourly SWE to warming air temperatures and precipitation changes was used to compare the effects of perturbed forcing meteorology on snow regime. The kernel density estimation (a non-parametric approach) was used. This estimation is based on a normal kernel function and a window parameter (bandwidth) that is a function of the length of the time series (Wolf Creek, $n=18$ years $x 365$ days $\times 24$ hours ; Marmot Creek, $n=9 \times 365 \times 24$; Reynolds Mountain, $n=25 x$ $365 x$ 24 ). The Kolmogorov-Smirnov (K-S) test (Massey Jr., 195) was used to compare the simulations to observations using a significance level of [?] 0.05.

Sensitivities of snow and streamflow regimes per $1 \mathrm{deg} C$ warming were estimated by averaging responses to the 30 combinations of warming and precipitation change in the three mountain basins. Sensitivities of five main characteristics that describe a basin snow regime were investigated. These characteristics are the timing of snowcover initiation (snow season start), snow-free date (snow season end), duration of the snow season, duration of snowmelt period, and magnitude of the peak snowpack. The duration of the snow season is the difference between the date of snowcover initiation and the date the basin becomes snow free. The duration of the melt period is the difference between the date of peak SWE and the date the basin becomes snow free.

\section{Results}

The magnitude and timing of annual peak snowpack is sensitive to both air temperature and precipitation changes in Wolf Creek as shown in Figure 3. The interaction between air temperature and precipitation affecting peak SWE is evident in the curvature and slope of the contours; the interaction is complex in the alpine and shrub tundra (curved contour lines, Figure 3a \& c) but less so in the forest (Figure 3e). The sensitivity of peak SWE to precipitation is somewhat higher in the high elevation alpine zone (contours have higher slope) and its sensitivity to temperature is somewhat higher in the lower elevation shrub tundra and forest zones (contours have lower slope). The peak SWE in the shrub tundra zone is very sensitive to a decrease in precipitation with warming due to precipitation phase change and suppression of blowing snow redistribution from the alpine zone under warmer air temperatures (Rasouli et al., 2014) and drops from $162 \mathrm{~mm}$ to $75 \mathrm{~mm}\left(87 \mathrm{~mm}\right.$ reduction, Figure 3c) with $80 \%$ of precipitation and $+5^{\circ} \mathrm{C}$ of warming. The sensitivity of peak SWE to increasing precipitation in the shrub tundra zone declines as the temperature 
warms. The peak SWE in the forested zone is slightly less sensitive to temperature than shrub tundra because unloading of intercepted snow from the canopy, where it is prone to sublimation, increases with winter air temperatures and moderates the impact of declining snowfall with rising temperature. Whether $20 \%$ additional precipitation can offset the effect of warming on snowpacks in Wolf Creek is illustrated in Figure 3 by comparing the black dot, indicating no change in air temperature or precipitation, to the white dot, indicating the degree of warming that can be offset by a $20 \%$ increase in precipitation. This is $3.5 \mathrm{degC}$ of warming for peak SWE in the alpine zone (Figure 3a) and 2.7degC and 3degC of warming for peak SWE in the shrub tundra (Figure 3c) and forest (Figure 3e).

There is no clear pattern to the small changes, less than six days, in the timing of peak SWE in the Wolf Creek alpine zone with air temperature and precipitation changes (Figure 3b). This is likely due to the persistently colder temperatures during winter at high elevations in the subarctic (Figure $3 \mathrm{~b}$ ). In the shrub tundra and forest, the mean annual peak SWE occurs 25 and 20 days earlier respectively with $5 \operatorname{deg} \mathrm{C}$ of warming and $20 \%$ reduced precipitation (Figure $3 \mathrm{~d}$ and $3 \mathrm{f}$ ).

In cold continental Marmot Creek, peak SWE in all zones is influenced by changes in both air temperature and precipitation but responds more strongly to temperature than in subarctic Wolf Creek (Figure 4). Peak SWE is progressively more influenced by warming temperature with declining elevation due to the influence of lapse rates on precipitation phase and other factors. Because of reduced blowing snow inputs from the alpine zone, the treeline forest zone loses the most snow $(-422 \mathrm{~mm}$ under $5 \mathrm{degC}$ of warming and $20 \%$ less precipitation, Figure 4c), but because it has the highest snow accumulation, snow is still deep and its proportional change with temperature was not substantially different from the other zones. In contrast, almost all snow is lost in the forest zone, suggesting a high sensitivity of snow in Marmot Creek's low elevation forests to warming because of the large losses of snow. The response of the peak SWE to warming and precipitation changes shows that an increase in precipitation of $20 \%$, slightly greater than the maximum indicated by climate models, can offset the effect on peak SWE of warming in the alpine of $2.9 \mathrm{degC}$ (Figure 4a), in the treeline forests of $2.1 \mathrm{deg} C$ (Figure $4 \mathrm{c}$ ) and in the forest and forest clearing of $1.8 \mathrm{degC}$ (Figure 4c, $\mathrm{g}$ ). The peak snowpack in Marmot Creek is more sensitive to warming, and so increased precipitation can offset less of a temperature increase than in Wolf Creek.

The changes in the simulated timing of peak SWE in Marmot Creek are substantial and complex. Timing responded much more to warming than to precipitation change and precipitation increases could not compensate for any degree of warming at any elevation (Figures $4 \mathrm{~b}, 4 \mathrm{~d}, 4 \mathrm{f}$, and $4 \mathrm{~h}$ ). In the alpine, forest, and forest clearing zones, peak SWE advanced between 19 and 28 days for $2 \mathrm{degC}$ of warming, and between 60 and 70 days for $5 \mathrm{degC}$. In contrast, the treeline forest peak SWE timing advanced only 10 and 27 days for 2 and $5 \mathrm{deg}$ C of warming, its lower sensitivity (range of contours) due to the high snow accumulation in this zone associated with continued redistribution of snow from the alpine (Figure 4d).

In Reynolds Mountain, annual peak SWE is very sensitive to increases in air temperature and much less sensitive to changes in precipitation (Figure $5 \mathrm{a}, 5 \mathrm{c}, 5 \mathrm{e}$, and $5 \mathrm{~g}$ ). The slope and curvature of the annual peak SWE contours show the sensitivity to precipitation change decreases as temperature increases. This suggests that the effects of warming on SWE cannot be easily offset by increased precipitation; a precipitation increase of $+20 \%$ can offset warming up to from 1.2 to $1.5 \mathrm{degC}$ depending on location. The warmest and driest scenario ( $+5 \mathrm{degC}$ and $-20 \%$ precipitation) caused the peak SWE decline in all zones, e.g., from 570 $\mathrm{mm}$ to $58 \mathrm{~mm}$ in the sink (Figure $5 \mathrm{a}$ ) and from $427 \mathrm{~mm}$ to $39 \mathrm{~mm}$ in the interception zones (Figure 5e). The blowing snow sink zone lost more snow with warming and drying than other zones due to the suppression of blowing snow transport from the source zone (Figure 5a). An increase in precipitation greater than $20 \%$ would be needed in Reynolds Mountain than in Wolf Creek and Marmot Creek to offset the effect of the same warming on peak SWE.

The response of the timing of annual peak SWE is much more sensitive to warming than to precipitation change in all zones in Reynolds Mountain (Figures 5b, 5d, 5f, and 5h). The timing changes in Reynolds Mountain are the largest of the three basins with the change in peak SWE date being between 50 and 70 days earlier for the maximum $5^{\circ} \mathrm{C}$ warming. Additional precipitation of $20 \%$ can only offset the effect of 
$0.5 \mathrm{deg} \mathrm{C}$ of warming on peak SWE date (Figures $5 \mathrm{~b}, 5 \mathrm{~d}, 5 \mathrm{f}$, and $5 \mathrm{~h}$ ).

The rate of change in the simulated snowpacks can be estimated in relation to temperature. Peak SWE reduction per degree of warming is $8 \%$ in Wolf Creek, $10 \%$ in Marmot Creek, and $17 \%$ in Reynolds Mountain (Table 1). The loss of snowpack with warming is reflected in the reduction in the snowcover duration of 11 days in Wolf Creek, 18 days in Marmot Creek, and 30 days in Reynolds Mountain per degree of warming (Table 1). The duration of snowmelt declines between 0 and 9 days per degree of warming in all basins, much less than the snowcover duration, and smaller than the advance in the timing of snow disappearance which ranges from 7 (Wolf Creek) to 13 (Marmot Creek) to 21 (Reynolds Mountain) days per degree of warming. Snow melts more slowly as the melt season advances in some of these simulations, which partly offsets the impact of the decrease in peak snowpack on snowmelt period duration.

In Wolf Creek, as in the other basins, the distribution of hourly simulations of SWE widens if precipitation increases and narrows if precipitation decreases (Figure 6). In the alpine, the accompanying warming shifts the distribution to the left and causes additional narrowing (Figure 6a). If the precipitation increase is large $(+20 \%)$; a warming of up to $3.5 \mathrm{deg}$ C can be offset for all hourly SWE simulations in all three zones in Wolf Creek (mean annual temperature exceeds $1.4 \mathrm{degC}$ ). In contrast to higher sensitivity of peak SWE in the forest zones, the distributions of different snowpack regimes show that the forest changes the least under warming and changes in precipitation because of cold sub-canopy winter temperatures and reduction in sublimation losses from intercepted snow with warming (Figure 6c). An increase in precipitation can offset the impacts of some warming and affects high and medium values of SWE the most and low SWEs only slightly (Figure 6). The warming impacts SWE in early winter during the initiation dates of snow accumulation and early spring during snow depletion more than peak snowpacks in all of the snow regimes (Table 1). The snowpack regime in Wolf Creek is more sensitive to changes in precipitation than to warming because of its consistently very cold winters. Each of the five distributions for the warming and changed precipitation scenarios in each zone are significantly different (p-value [?] 0.05) to the snowpack distribution in the base period (0degC warming, 100\% precipitation) based on the Kolmogorov-Smirnov (K-S) test.

In Marmot Creek, the distribution of hourly simulations of SWE is wider if precipitation increases and much narrower if temperature warms by more than $2 \mathrm{degC}$ (Figure 7). Precipitation increases of $20 \%$ can offset effect of a warming up to $2 \mathrm{deg} \mathrm{C}$ on snowpack regime in each zone (Figure 7) but cannot offset warming of more than $2 \mathrm{degC}$. The distributions of different snowpack regimes show that a very shallow snowpack (SWE $<100 \mathrm{~mm}$ ) is expected in the forest (Figure 7c) and forest clearings (Figure 7d) under the extreme case of $5 \mathrm{deg} \mathrm{C}$ warming and $20 \%$ decrease in precipitation. Warming impacts peak more than shallower snowpacks in all zones. An increase in precipitation can offset the impacts of warming by increasing SWE, especially high values of SWE (Figure 7). In general, the snowpack regime in Marmot Creek is equally sensitive to warming and changes in precipitation (Figure 4). Each of the five distributions for the warming and changed precipitation scenarios in each zone are significantly different (p-value [?] 0.05) to the modelled snowpack distribution in the base period based on the Kolmogorov-Smirnov (K-S) test.

In Reynolds Mountain, the distribution of hourly simulations of SWE is wider if precipitation increases, and much narrower if temperature warms by more than $1 \mathrm{degC}$ (Figure 8). Increasing precipitation offsets less of the warming impact in Reynolds Mountain than in Wolf Creek or in Marmot Creek; a precipitation increase of $20 \%$ can only offset the impact of a $1 \mathrm{degC}$ warming (mean annual temperature exceeds $6 \mathrm{degC}$ ). An additional $20 \%$ precipitation cannot offset warming of $2 \mathrm{degC}$ or more. The different snowpack regimes are sensitive to impacts of $5 \mathrm{deg} \mathrm{C}$ warming and $20 \%$ decrease in precipitation (Figure 8 ) and simulated maximum SWE values drop below $240 \mathrm{~mm}$ from the base case of over $800 \mathrm{~mm}$ in the source and sink HRUs (Figure 8a), interception (Figure 8c), and sheltered regime (Figure 8d). Of particular interest is that high values of SWE $(>500 \mathrm{~mm})$ do not occur. Each of the five distributions for the warming and changed precipitation scenarios in each zone are significantly different (p-value [?] 0.05) to the snowpack distribution in the base period based on the Kolmogorov-Smirnov (K-S) test.

Changes in the distribution of SWE in each headwater basin show that the zones in Wolf Creek (Figure 6) and the treeline forest in Marmot Creek (Figure 7b) are the least sensitive to air temperature and 
precipitation changes. Each of the regimes in Reynolds Mountain (Figure 8) are sensitive in terms of the absolute magnitude of snow loss.

The sensitivity of five main characteristics of basin snow regimes to warming and change in precipitation averaged over Wolf Creek shows that both changes in precipitation and warming affect the magnitude of the peak SWE (Figure 9a). Precipitation increases of $20 \%$ can offset a $3 \mathrm{deg} C$ temperature increase in Wolf Creek peak SWE. Delay in the initiation of snow accumulation is sensitive to warming rates above 3degC regardless of precipitation changes (Figure 9b). The snow-free date advances from late-June (June 28) in the recent climate to early June (June 11) with a warming of $2 \mathrm{degC}$ (Figure 9c, Table 2). The snow-free date is also sensitive to warming and almost insensitive to precipitation changes (Figure 9c). The snow season duration in Wolf Creek is also driven by warming and not by precipitation changes (Figure 9d). The snowmelt period, the timing difference between peak SWE and the snow-free date, is sensitive to warming and almost insensitive to precipitation changes (Figure 9e).

In Marmot Creek, the peak SWE drops from $220 \mathrm{~mm}$ to $92 \mathrm{~mm}$ under a warming of $5 \mathrm{deg} \mathrm{C}$ and decreasing precipitation (20\%), (Figure 9f, Table 2). The start of snow accumulation is not affected to a large amount by either warming or precipitation (Figure $9 \mathrm{~g}$ ), but increased temperatures have a large effect on the end date (Figure 9h) and snow season duration (Figure 9i) but this is reduced with increased precipitation. The duration of the melt season also is not affected (Figure 9j). In contrast to Wolf Creek, the initiation date of snow accumulation is sensitive to precipitation changes and would advance if warming rates are below $2 \mathrm{deg} \mathrm{C}$ and precipitation increases. The snow-free date advances from early June in the recent climate to late May with a warming of $2 \mathrm{degC}$ (Figure $9 \mathrm{~h}$ ). Similar to the ablation period, snow accumulation start date is sensitive to precipitation changes and to a lesser extent to warming. With concomitant warming (5degC) and decreasing precipitation, the snow-free date across the basin advances by 77 days to late March (Figure 9h). As shown in Figure 9, the snow-free date is sensitive to warming and insensitive to precipitation changes in Marmot Creek and snow season length is affected by both warming and precipitation changes. Similar to Wolf Creek, the combination of air temperature increasing by at least $2 \mathrm{deg} \mathrm{C}$ and precipitation increasing by less than $20 \%$ results in declining peak SWE and deviation from the historical ranges of snowpack in Marmot Creek.

In Reynolds Mountain, warming of $5 \mathrm{degC}$ and decreasing precipitation of $20 \%$, the mean annual peak SWE decreases from $390 \mathrm{~mm}$ to $47 \mathrm{~mm}$ (Figure 9k, Table 2), snow accumulation starts later (Figure 9l) and ends earlier (Figure 9m). The duration of the snow season (Figure 9n) and duration of the melt period snow season (Figure 9o) become much shorter than in present climate (Table 2). A 1degC warming advances the timing of peak SWE by approximately 15 days (Table 1 ). The magnitude of peak SWE is more sensitive to temperature than precipitation (Figure 9k); the timing of the snow regime sensitive to temperature and less so to precipitation (Figure 9 l-o).

The peak SWE is $136 \mathrm{~mm}$ in Wolf Creek, $220 \mathrm{~mm}$ in Marmot Creek, and $390 \mathrm{~mm}$ in Reynolds Mountain; Wolf Creek and Reynolds peak SWE occur in early March, and in Marmot Creek it occurs in late April (Table 2). With a $20 \%$ decline in precipitation and a warming of $5 \mathrm{deg} \mathrm{C}$ peak SWE declines to $61 \mathrm{~mm}(55 \%$ decrease) in Wolf Creek, to $92 \mathrm{~mm}(58 \%)$ in Marmot Creek, and to $47 \mathrm{~mm}$ (88\% decrease) in Reynolds Mountain. With a $20 \%$ increase in precipitation and no warming and peak SWE increases to $169 \mathrm{~mm}(24 \%)$ in Wolf Creek, to $281 \mathrm{~mm}$ in Marmot Creek (28\%), and to $486 \mathrm{~mm}(25 \%)$ in Reynolds Mountain. With $5 \mathrm{deg} \mathrm{C}$ warming and no changes in precipitation, the onset of snow accumulation is delayed 17 days in Wolf Creek, 23 days in Marmot Creek, and 42 days in Reynolds Mountain and the end of winter comes earlier by 37 days in Wolf Creek, 67 days in Marmot Creek, and 104 days in Reynolds Mountain. When compared to no changes (Table 2), a $20 \%$ increase in precipitation would lengthen the snowcover duration by 5 to 20 days.

The simulations show that changes in snow regime in these mountain basins also result in moderated changes in mean annual runoff. Unlike peak SWE, mean annual runoff is more sensitive to changes in precipitation than air temperature (Figure 10). The near vertical lines in Figure 10a \& b indicate that changes in mean annual runoff are driven predominately by precipitation in Wolf Creek and Marmot Creek while in Reynolds 
Mountain temperature more strongly impacts runoff. A 1degC warming in Wolf Creek resulted in a 5\% decrease in the annual runoff (Table 1); total decreases rise to ${ }^{14 \%}$ for a $5 \mathrm{degC}$ warming (171 to 147 $\mathrm{mm}$, Table 2, Figure 10a). The most extreme scenario of climate warming and decreased precipitation caused larger declines in runoff, but if precipitation increases there is strong compensation. For instance, if precipitation increases by $20 \%$ then annual runoff increases by $35 \mathrm{~mm}$ (from 171 to $206 \mathrm{~mm}$ ) with $5 \mathrm{degC}$ of warming. Mean annual runoff is more sensitive than snow regime to precipitation change in Wolf Creek. Similarly, in Marmot Creek, a $5 \mathrm{degC}$ increase in air temperature results in a $4 \%$ decrease in the mean annual runoff (402 to $384 \mathrm{~mm}$ Table 2, Figure 10b). The combination of $5 \mathrm{degC}$ of warming and $20 \%$ decreased precipitation reduces mean annual runoff by $34 \%$ (135 $\mathrm{mm}$ from 402 to $267 \mathrm{~mm}$, Table 2, Figure 10b). In Reynolds Mountain, mean annual runoff has a stronger temperature sensitivity than Wolf Creek or Marmot Creek (Figure 10). A 5degC increase in temperature results in a 29\% (371 to $263 \mathrm{~mm}$, Table 2) decrease in the mean annual runoff. The combination of $5 \mathrm{degC}$ of warming and $20 \%$ decrease in precipitation reduces annual runoff by $43 \%$, (371 to $161 \mathrm{~mm}$, Table 2 ).

Changes in mean annual runoff (Figure 10) contrasts with the change in mean annual peak SWE (Figures 3-5) in that mean annual runoff is more sensitive to precipitation than temperature. The sensitivity of annual runoff to temperature increase in Reynolds Mountain is because of the longer snow-free season and an increased growing season and energy flux for evapotranspiration with increasing temperature (Figure 5) whilst runoff responds to both precipitation change and warming (Figure 10c). In contrast to the sensitivity of snowpack to warming in Reynolds Mountain, annual runoff is less sensitive, and the impact of warming on annual runoff can be partly offset by an increase in precipitation in Reynolds Mountain.

Annual runoff changes are given in Table 2 under different scenarios of warming and changes in precipitation. Annual runoff responds strongly to precipitation changes in Wolf Creek and Marmot Creek, and to both warming and precipitation changes in Reynolds Mountain. The annual runoff is the most resilient to warming in Marmot Creek and most sensitive to warming in Reynolds Mountain. Under 5degC and a $20 \%$ increased precipitation, annual runoff increases from $171 \mathrm{~mm}$ to $206 \mathrm{~mm}$ (20\%) in Wolf Creek and increases from 402 $\mathrm{mm}$ to $518 \mathrm{~mm}$ (29\%) in Marmot Creek and from $371 \mathrm{~mm}$ to $415 \mathrm{~mm}$ (12\%) in Reynolds Mountain (Table 1). This shows that increased precipitation with warming increases the runoff in Marmot Creek more than the other two basins. This is due to the very cold alpine snowpack at Marmot Creek which is relatively unaffected by warming and the warm snowpacks at Reynolds Mountain which become ephemeral with warming.

From this sensitivity analysis, the amount of additional precipitation needed to offset the effect of increased temperature on peak SWE, and annual runoff under future climate can be estimated. The largest increase in precipitation projected by RCPs and NARCCAP RCM-GCMs is $34 \%$ for Wolf Creek, $18 \%$ for Marmot Creek, and $16 \%$ for Reynolds Mountain. In Wolf Creek, when warming is limited to 1degC, increased precipitation of $4 \%$ is able to offset the effect of warming on peak SWE (Figure 11a); but, with warming of $5 \mathrm{deg} \mathrm{C}$, an increase in precipitation of $34 \%$, the amount expected from RCPs and NARCCAP, would be required to offset the effect of warming. In Marmot Creek, the effect of a $1 \mathrm{deg} C$ warming on peak SWE can be offset by an $8 \%$ increase in precipitation; however, the effect of a $5 \mathrm{degC}$ warming on peak $\mathrm{SWE}$ would require precipitation increases that are greater than expected from RCP scenarios and NARCCAP simulations. In Reynolds Mountain, the impact of a $1 \mathrm{degC}$ warming on peak SWE can be offset by a $16 \%$ increase in precipitation, but the offset required for more than $2 \operatorname{deg} \mathrm{C}$ warming exceeds the projected maximum precipitation increases.

Annual runoff is less sensitive than peak snowpack to warming and smaller precipitation increases are required to offset the effects of warming simulated here. These differences are due to differences in the fraction of snow converted to rainfall in each basin under a warmer climate. The additional precipitation needed to offset the impact of warming on runoff varies with elevation range, precipitation regime and latitude; offsetting the effect of warming of $5 \mathrm{degC}$ on annual runoff would require precipitation increases of $8 \%$ in Wolf Creek (Figure 11a), 3\% in Marmot Creek (Figure 11b), and 14\% in Reynolds Mountain (Figure 11c). 


\section{Discussion}

Air temperatures in late winter and spring have a key role in determining the sensitivity of snowpack in mountain basins to warming (Lettenmaier and Gan, 1990; Stewart et al., 2004; McCabe and Clark, 2005). The results presented above demonstrate and quantify the sensitivity of annual peak snowpack and its timing, and of annual runoff, to air temperature and precipitation changes and their interaction in the three basins. Sensitivity of annual peak snowpack timing to air temperature and precipitation changes in the three basins shows that the sensitivity of peak SWE timing to precipitation changes is greater in the colder climate conditions: Reynolds Mountain responds to warming only (Figure 5), Marmot Creek responds to warming and to a lesser extent to precipitation (Figure 4); and Wolf Creek responds to a complex interaction of warming and precipitation change (Figure 3). The potential for precipitation to counteract the effect of warming on the magnitude of the annual peak snowpack, becomes smaller moving from northern latitudes to southern latitudes. Therefore, regional responses to warming and changes to precipitation must be considered (Bower et al., 2004), particularly when evaluating future mountain hydrology (Roche et al., 2018; Sultana and Choi, 2018). This is because the snowpack is shallow and warm at the beginning and end of the season; shallow warm snow ripens and melts faster than deep cold snow as it requires less energy input to overcome cold content and fill its liquid water holding capacity (Colbeck, 1976).

Simulations of future conditions for snow regimes in Reynolds Mountain are in accord with the SWE magnitude and timing trajectories of the past 50 years (Nayak et al., 2010). Higher rates of warming and increased precipitation are projected by RCMs in the northern latitudes (Mearns et al., 2007). Latitudinal change in the role of precipitation increase in offsetting the effect of warming on cold regions hydrology implies that, even though northern latitudes will warm more (Graversen et al., 2008), they will also have more precipitation. Therefore, the precipitation increase may offset the impact of warming on snow and hydrological regimes in northern basins. It is also expected that the response of hydrological processes in different latitudes to the same climatic change will differ.

Although the snow regime in Marmot Creek (Figure 4) is as sensitive as in Wolf Creek (Figure 3) to warming and a decrease in precipitation, its runoff regime is less sensitive than the runoff regime in Wolf Creek (Figure 9). These results are consistent with findings and projections for other mountain areas (Sultana and Choi, 2018; Roche et al., 2018; Jennings and Moltoch, 2019; Lopez-Moreno et al., 2020). The relatively lower sensitivity of the forest peak snow in Wolf Creek (Figure 3e) is because of the increased unloading of intercepted snow at warmer air temperatures that counteracts the reduced snowfall (Pomeroy et al., 2015). The higher resiliency of the Marmot Creek snowpack is due to smaller changes at high elevations and in the blowing snow sink zone of the treeline forest in which a deep snowpack is deposited that remains until midsummer (MacDonald et al., 2010; Harder et al., 2015; Rasouli et al., 2019a). High elevation and high latitude basins are more resilient to warming because their temperatures are currently well below that required to shift precipitation phase (Bavay et al., 2013; Jennings and Moltoch, 2019). The snowpack lasts longer on the ground at high elevations in Marmot Creek, which moderates the impact of snow loss at low elevations on runoff (Rasouli et al., 2019a; Lopez-Moreno et al., 2020). A high elevation band with air temperatures similar to that in low elevations in Wolf Creek and a rainy environment in the spring and early summer peak runoff period (Pomeroy et al., 2016) explain why the drop in peak snow accumulation is not reflected by a proportional drop in annual runoff in Marmot Creek. This highlights the role of the spatial redistribution of snow on heterogeneous hydrological responses at different elevations in Marmot Creek. The snow and runoff regimes are the most sensitive to warming in Reynolds Mountain because of the (i) higher annual mean air temperature, (ii) near-freezing air temperatures in winter, and (iii) fewer number of days with freezing temperatures (120 days a year, Rasouli et al., 2019a). Rasouli et al. (2019a) found that under a moderate warming and increased precipitation of $7 \%$ and $2 \%$ in Marmot Creek and Reynolds Mountain, respectively, the annual runoff remained unchanged due to the offsetting effect of increased precipitation on increased evapotranspiration and offsetting effect of decreased sublimation on reduced snowfall (Rasouli et al., 2019a). Less sensitivity of annual runoff to warming relative to snowpacks suggests that warming mountain snowpacks can be decoupled from hydrological regimes (Lopez-Moreno et al., 2020). Snowpack 
regimes in Reynolds Mountain are more sensitive to warming than to changes in precipitation, similar to the Cascade Mountains of Oregon, USA (Sproles et al., 2013).

Estimated snowpack reduction per degree increase of temperature is $8 \%$ in Wolf Creek, $10 \%$ in Marmot Creek, and $17 \%$ in Reynolds Mountain (Table 2). In Wolf Creek these results are similar to reductions observed in the Svalbard Archipelago ( 79deg N, Lopez-Moreno et al., 2016). Snowpack loss in Marmot Creek is in the range of 11-20\% reduction reported for the Pyrenees (Lopez-Moreno et al., 2013, 2014) and comparable to a $15 \%$ reduction reported for the Swiss Alps (Beniston et al., 2003). Snow loss per degree of warming in Reynolds Mountain is similar to a $20 \%$ reduction reported for the Washington Cascades (Casola et al., 2009). The results here are consistent with other basins with similar climates and that climate change affects snowpack in mountain basins across the globe with large reductions at mid-latitudes and relatively small reductions at high latitudes (Roche et al., 2018; Sultana and Choi, 2018).

Under a severe warming of $5 \mathrm{degC}$ and a $20 \%$ increased precipitation, annual runoff increases in all three basins (Table 2) because of the increasing importance of rain in warmer climates, suggesting that precipitation increase has a primary role in changing annual total runoff and there is a large shift in the runoff mechanism from being snowmelt-driven to rainfall-driven. This shift may result in reduced streamflow (Berghuis et al., 2014 ) if precipitation does not increase (Table 2). It might also alter forest vegetation over time by making it more prone to wildfire and disease.

\section{Offsetting temperature increases}

The impact of warming of $1 \mathrm{degC}$ on SWE values over the winter and spring seasons can be offset by a precipitation increase of $20 \%$ for almost all SWE values in all snow regimes in Reynolds Mountain; however, warming of $2 \mathrm{degC}$ or more cannot be offset by increases in precipitation of less than $20 \%$. The sensitivity of SWE in the blowing snow source and sink HRUs to warming is higher than that in the forested intercepted snow and sheltered forest gap HRUs; this is due to suppression of blowing snow redistribution processes by warming. In Wolf Creek $(\approx 61 \mathrm{deg} N)$, not only more warming but also an increase in precipitation is expected (Graversen et al., 2008), which indicates that precipitation increases could partly offset the effect of warming on cold regions hydrology. Despite the uniformity of high mountain climates and similar response per degree increase in temperature, the implication of these results is that mountain snow regime responses to climate change will differ substantially (Lopez-Moreno et al., 2020), as noted for the three basins across North America studied here, therefore regional analysis is required. The large difference between snowpack response in Reynolds Mountain and Wolf Creek implies that warming in cool climates impacts the maximum accumulated snowpack more than it does in cold climates. Warming affects the phase of precipitation, causing a shift from snowfall to rainfall in the spring and fall transition seasons (Poulin et al., 2011; Whitfield and Shook, 2020) and a shift from March to January in Reynolds Mountain, April to February in Marmot Creek and less than a month in Wolf Creek for the timing of peak snow accumulation (Table 2). The impacts of warming on snowpacks can be partly offset by a precipitation increase in the cold Wolf Creek and Marmot Creek climates but not in the cool Reynolds Mountain climate. The snow season is expected to shorten by about two months in the subarctic Wolf Creek (from 9 to 7 months), three and half months in the cold Marmot Creek (from 6 to 4 months), and five months in the cool Reynolds Mountain basin (from 6 to 1 month) with concomitant warming and a decline in precipitation (Table 2). This implies that, if warming occurs, the response of the snow hydrology to a precipitation increase changes with latitude from very little in Reynolds Mountain to very large in Wolf Creek. Snow hydrology is more sensitive to warming and precipitation phase change in the southern basin and more resilient in Marmot Creek.

\section{Conclusions}

Annual perturbations of observed hourly air temperature and precipitation were used to drive physically based cold regions hydrological models of the sensitivity of snow and runoff regimes in well-instrumented mountain research basins that span the northern North American Cordillera. Peak snowpack is sensitive 
to both warming and precipitation change in Wolf Creek in the subarctic Yukon and more sensitive to temperature in Reynolds Mountain in temperate Idaho. Peak snowpack is most sensitive to warming in the sheltered site in Reynolds Mountain and to both warming and precipitation change in the blowing snow sink regime in Reynolds Mountain, at lower elevations in Marmot Creek, and shrub tundra zone in Wolf Creek. Peak snowpack timing is more sensitive to temperature in Marmot Creek and Reynolds Mountain, but in Wolf Creek, precipitation more strongly affects the timing of peak SWE as temperatures remain largely below zero. Snow season start, end, and duration were found to be sensitive to warming in temperate Idaho and subarctic Yukon and to both warming and precipitation change in the continental Canadian Rockies (Marmot Creek).

The scenario with a severe climate warming and decreased precipitation in all three basins caused dramatic declines in SWE, a shortened snow-covered period, and decreases in annual runoff. The decreases in depth and advance in the timing of peak snowpack are weakly reflected in changes to runoff regime in each basin. The large changes in snowpack found here do not result in similar magnitude changes in annual runoff.

If precipitation decreases with warming, the impacts on snowpacks are amplified, with major implications for ecology, winter transportation, and hydrology. Smaller snowpacks and warmer weather would cause an increase in the snow-free period, which also would lengthen the evapotranspiration season, increasing the annual evapotranspiration loss. The importance of rainfall-runoff mechanisms in these basins increases while snowmelt decreases. Under warmer and drier climatic conditions, annual runoff decreases.

Increased precipitation, expected from some climate projections, can partially offset the effect of warming on snowpack and annual runoff. The role of precipitation as a compensator for the impact of warming on mountain snow hydrology is most effective in the colder high elevations and high latitudes and its effectiveness is reduced where snow regimes currently depend on blowing snow deposition, which is very sensitive to temperature. With increased precipitation, high elevation and high latitude basin snow and hydrological regimes can be resilient to warming. However, at lower elevations, and at lower latitudes the impact of warming cannot be offset by the projected maximum precipitation increases in future climates. The coupling of snow regimes to streamflow hydrology will remain strong in northern Canada but weaker in the mountains of Idaho and Alberta as the climate warms.

\section{Acknowledgments}

The long-term commitment of Danny Marks of the USDA Agricultural Research Service for Reynolds Mountain, and the late Rick Janowicz of Yukon Environment for Wolf Creek, and the contribution of many technicians and students to data collection and experiments in the three research basins is appreciated. The Natural Sciences and Engineering Research Council of Canada funded this research through Discovery Grants and the Changing Cold Regions Network. KR was supported by an Alexander Graham Bell Canada Graduate Scholarship-Doctoral Program and a NSERC Postdoctoral fellowship. The study was further supported by the Canada Research Chairs and Global Water Futures programmes. The support of Xing Fang and Tom Brown on CRHM hydrological modelling and particularly for the Marmot Creek model is greatly appreciated.

\section{References}

Arnell, N.W., 1999. The effect of climate change on hydrological regimes in Europe: a continental perspective. Glob. Environ. Change 9(1), 5-23. https://doi.org/10.1016/S0959-3780(98)00015-6

Bales, R.C., Molotch, N.P., Painter, T.H., Dettinger, M.D., Rice, R., Dozier, J., 2006. Mountain hydrology of the western United States. Water Resour. Res. 42. https://doi.org/10.1029/2005WR004387 
Barros, V.R., Field, C.B., Dokke, D.J., Mastrandrea, M.D., Mach, K.J., Bilir, T.E., Chatterjee, M., Ebi, K.L., Estrada, Y.O., Genova, R.C., Girma, B., Kissel, E.S., Levy, A.N., MacCracken, S., Mastrandrea, P.R., White, L.L., 2014. Climate Change 2014: Impacts, Adaptation, and Vulnerability. Part B: Regional Aspects. Contribution of Working Group II to the Fifth Assessment Report of the Intergovernmental Panel on Climate Change. Cambridge University Press. Pp. 190

Barry, R.G., 1992. Mountain climatology and past and potential future climatic changes in mountain regions: A review. Mt. Res. Dev. 12, 71-86. https://doi.org/10.2307/3673749

Bavay, M., Grunewald, T., Lehning, M., 2013. Response of snow cover and runoff to climate change in high Alpine catchments of Eastern Switzerland. Adv. Water Resour. 55, 4-16. https://doi.org/10.1016/j.advwatres.2012.12.009

Beniston, M., 2003. Climatic change in mountain regions: a review of possible impacts, in: Climate variability and change in high elevation regions: past, present \& future. Clim. Change 59, 5-31. https://doi.org/10.1023/A:1024416227887

Beniston, M., Keller, F., Ko, B., Goyette, S., 2003. Estimates of snow accumulation and volume in the Swiss Alps under changing climatic conditions. Theor. Appl. Climatol. 76, 125-140. https://doi.org/10.1007/s00704-003-0016-5

Berghuijs, W.R., Woods, R.A., Hrachowitz M., 2014. A precipitation shift from snow towards rain leads to a decrease in streamflow. Nat. Clim. Change 4(7), 583-586. https://doi.org/10.1038/nclimate2246

Bower, D., Hannah, D.M., McGregor, G.R., 2004. Techniques for assessing the climatic sensitivity of river flow regimes. Hydrol. Process. 18, 2515-2543. https://doi.org/10.1002/hyp.1479

Bunbury, J., Gajewski, K., 2012. Temperatures of the past 2000 years inferred from lake sediments, southwest Yukon Territory, Canada. Quat. Res. 77, 355- 367. https://doi.org/10.1016/j.yqres.2012.01.002

Casola, J.H., Cuo, L., Livneh, B., Lettenmaier, D.P., Stoelinga, M.T., Mote, P.W., Wallace, J.M., 2009. Assessing the impacts of global warming on snowpack in the Washington Cascades. J. Clim. 22, 2758-2772. https://doi.org/10.1175/2008JCLI2612.1

Cayan, D.R., 1996. Interannual climate variability and snowpack in the western United States. J. Clim. 9, 928-947. https://doi.org/10.1175/1520-0442(1996)009<0928:ICVASI > 2.0.CO;2

Colbeck, S.C., 1976. An analysis of water flow in dry snow. Water Resour. Res. 12(3), 523-527. https://doi.org/10.1029/WR012i003p00523

Diaz, H.F., Grosjean, M., Graumlich, L., 2003. Climate variability and change in high elevation regions: past, present and future. Clim. Change. 59(1-2), 1-4. https://doi.org/10.1023/A:1024416227887

Fang, X., Pomeroy, J.W., 2020. Diagnosis of future changes in hydrology for a Canadian Rockies headwater basin. Hydrol. Earth Syst. Sci., 24, 2731-2754. https://doi.org/10.5194/hess-24-2731-2020.

Fang, X., Pomeroy, J.W., DeBeer, C.M., Harder, P., Siemens, E., 2019. Hydrometeorological data from Marmot Creek Research Basin, Canadian Rockies. Earth Syst. Sci. Data 11(2), 455-471. https://doi.org/10.5194/essd-11-455-2019

Fang, X., Pomeroy, J.W., Ellis, C.R., MacDonald, M.K., DeBeer, C.M., Brown, T., 2013. Multi-variable evaluation of hydrological model predictions for a headwater basin in the Canadian Rocky Mountains. Hydrol. Earth Syst. Sci. 17(4), 1635-1659. https://doi.org/10.5194/hess-17-1635-2013

Fowler, H., Blenkinsop, S., Tebaldi, C., 2007. Linking climate change modelling to impacts studies: recent advances in downscaling techniques for hydrological modelling. Int. J. Climatol. 27, 1547- 1578. https://doi.org/10.1002/joc.1556 
Fyfe, J.C., Flato, G.M., 1999. Enhanced climate change and its detection over the Rocky Mountains. J. Clim. 12, 230-243. https://doi.org/10.1175/1520-0442(1999)012<0230:ECCAID >2.0.CO;2

Graversen, R.G., Mauritsen, T., Tjernstrom, M., Kallen, E., Svensson, G., 2008. Vertical structure of recent Arctic warming. Nature 451, 53-56. https://doi.org/10.1038/nature06502

Harder, P., Pomeroy, J.W., Westbrook, C.J., 2015. Hydrological resilience of a Canadian Rockies headwaters basin subject to changing climate, extreme weather, and forest management. Hydrol. Process. 29, 39053924. https://doi.org/10.1002/hyp.10596

Hay, L.E., Wilby, R.L., Leavesley, G.H., 2000. A comparison of delta change and downscaled GCM scenarios for three mountainous basins in the United States. J. Am. Water Resour. Assoc. 36, 387-397. https://doi.org/10.1111/j.1752-1688.2000.tb04276.x

Jennings, K.S., Molotch, N.P., 2019. The sensitivity of modeled snow accumulation and melt to precipitation phase methods across a climatic gradient, Hydrol. Earth Syst. Sci. 3765-3786. https://doi.org/10.5194/hess-23-3765-2019.

Jasper, K., Calanca, P., Gyalistras, D., Fuhrer, J., 2004. Differential impacts of climate change on the hydrology of two alpine river basins. Clim. Res. 26, 113-129. https://doi.org/10.3354/cr026113

Kawase, H., Yoshikane, T., Hara, M., Kimura, F., Yasunari, T., Ailikun, B., Ueda, H., Inoue, T., 2009. Intermodel variability of future changes in the Baiu rainband estimated by the pseudo global warming downscaling method. J. Geophys. Res. Atmos. 114. https://doi.org/10.1029/2009JD011803.

Kay, A., Davies, H., Bell, V., Jones, R., 2009. Comparison of uncertainty sources for climate change impacts: flood frequency in England. Clim. Change 92, 41-63. https://doi.org/10.1007/s10584-008-9471-4

Lettenmaier, D. P., and T. Y. Gan (1990), Hydrologic sensitivities of the Sacramento-San Joaquin River basin, California, to global warming. Water Resour. Res. 26(1), 69-86. https://doi.org/10.1029/WR026i001p00069

Lopez-Moreno, J., Boike, J., Sanchez-Lorenzo, A., Pomeroy, J., 2016. Impact of climate warming on snow processes in Ny-Alesund, a polar maritime site at Svalbard. Glob. Planet. Change 146, 10-21. https://doi.org/10.1016/j.gloplacha.2016.09.006

Lopez-Moreno, J., Pomeroy, J., Revuelto, J., Vicente-Serrano, S., 2013. Response of snow processes to climate change: spatial variability in a small basin in the Spanish Pyrenees. Hydrol. Process. 27, 26372650. https://doi.org/10.1002/hyp.9408

Lopez-Moreno, J.I., Revuelto, J., Gilaberte, M., Moran-Tejeda, E., Pons, M., Jover, E., Esteban, P., Garca, C., Pomeroy, J., 2014. The effect of slope aspect on the response of snowpack to climate warming in the Pyrenees. Theor. Appl. Climatol. 117, 207-219. https://doi.org/10.1007/s00704-013-0991-0

Lopez-Moreno, J.I., Pomeroy, J.W., Alonso-Gonzalez, E., Moran-Tejeda, E., Revuelto, J., 2020. Decoupling of warming mountain snowpacks from hydrological regimes. Environ. Res. Lett. 15(11), 114006. https://doi.org/10.1088/1748-9326/abb55f

Luo, Y., Gerten, D., Le Maire, G., Parton, W. J., Weng, E., Zhou, X., Keough, C., Beier, C., Ciais, P., Cramer, W., 2008. Modeled interactive effects of precipitation, temperature, and $\left[\mathrm{CO}_{2}\right]$ on ecosystem carbon and water dynamics in different climatic zones. Glob. Chang. Biol., 14(9), 1986-1999. https://doi.org/10.1111/j.1365-2486.2008.01629.x

MacDonald, R. J., Byrne, J. M., Kienzle, S. W., Larson, R.P., 2010. Assessing the Potential Impacts of Climate Change on Mountain Snowpack in the St. Mary River Watershed, Montana. J. Hydrometeorol. 12, 262-273. https://doi.org/10.1175/2010JHM1294.1

Malmqvist, B., Rundle, S., 2002. Threats to the running water ecosystems of the world. Environ. Conserv. 29, 134-153. https://doi.org/10.1017/S0376892902000097 
Marks, D., Kimball, J., Tingey, D., Link T., 1998. The sensitivity of snowmelt processes to climate conditions and forest cover during rain-on-snow: a case study of the 1996 Pacific Northwest flood. Hydrol. Process. 12, 1569-1587. https://doi.org/10.1002/(SICI)1099-1085(199808/09)12:10/11<1569::AID-HYP682>3.0.CO;2-L

Massey Jr., F.J., 1951. The Kolmogorov-Smirnov test for goodness of fit. J. Am. Stat. Assoc. 46, 68-78. https://doi.org/10.1080/01621459.1951.10500769

McCabe, G.J., Clark, M.P., 2005. Trends and variability in snowmelt runoff in the western United States. J. Hydrometeorol. 6, 476-482. https://doi.org/10.1175/JHM428.1

Mearns, L., Gutowski, W., Jones, R., Leung, L., McGinnis, S., Nunes, A., Qian, Y., 2007. The North American regional climate change assessment program dataset, National Center for Atmospheric Research Earth System Grid Data Portal, Boulder, CO. https://doi.org/10.5065/D6RN35ST, data accessed Sept 2013.

Meybeck, M., Green, P., Vorosmarty, C., 2001. A new typology for mountains and other relief classes: An application to global continental water resources and population distribution. Mt. Res. Dev. 21, 34-45. https://doi.org/10.1659/0276-4741(2001)021[0034:ANTFMA]2.0.CO;2

Minder, J. R., 2010. The sensitivity of mountain snowpack accumulation to climate warming. J. Clim. 23(10), 2634-2650. https://doi.org/10.1175/2009JCLI3263.1

Moss, R.H., Edmonds, J.A., Hibbard, K.A., Manning, M.R., Rose, S.K., Van Vuuren, D.P., Carter, T.R., Emori, S., Kainuma, M., Kram, T., et al., 2010. The next generation of scenarios for climate change research and assessment. Nature 463, 747-756. https://doi.org/10.1038/nature08823

Mote, P.W., Hamlet, A.F., Clark, M.P. Lettenmaier, D.P., 2005. Declining mountain snowpack in western North America. Bull. Am. Meteorol. Soc. 86(1), 39-50. https://doi.org/10.1175/BAMS-86-1-39

Nayak, A., 2008. The effect of climate change on the hydrology of a mountainous catchment in the western United States: A case study at Reynolds Creek, Idaho. Utah State University. Pp. 194. https://digitalcommons.usu.edu/etd/82

Nayak, A., Marks, D., Chandler, D., Seyfried, M., 2010. Long-term snow, climate, and streamflow trends at the Reynolds Creek Experimental watershed, Owyhee Mountains, Idaho, United States. Water Resour. Res. 46. https://doi.org/10.1029/2008WR007525

Pederson, G.T., Gray, S.T., Ault, T.R., Marsh, W., Fagre, D.B., Bunn, A.G., Woodhouse, C.A., Graumlich, L.J., 2011. Climatic Controls on the Snowmelt Hydrology of the Northern Rocky Mountains. J. Clim. 24, 1666-1687. https://doi.org/10.1175/2010JCLI3729.1

Pomeroy, J., Gray, D., Brown, T., Hedstrom, N., Quinton, W., Granger, R., Carey, S., 2007. The cold regions hydrological model: a platform for basing process representation and model structure on physical evidence. Hydrol. Process. 21, 2650-2667. https://doi.org/10.1002/hyp.6787

Pomeroy, J.W., Fang, X., Rasouli, K., 2015. Sensitivity of snow processes to warming in the Canadian Rockies. In Proceedings, 72nd Eastern Snow Conference, 9-11 June 2015, Sherbrooke, Quebec, Canada, $22-33$.

Pomeroy, J.W., Fang, X., Marks, D.G., 2016. The cold rain-on-snow event of June 2013 in the Canadian Rockies - Characteristics and diagnosis. Hydrological Processes, 30(17), 2899-2914. https://doi.org/10.1002/hyp.10905

Poulin, A., Brissette, F., Leconte, R., Arsenault, R., Malo, J.-S. 2011. Uncertainty of hydrological modelling in climate change impact studies in a Canadian, snow-dominated river basin. J. Hydrol. 409, 626-636. https://doi.org/10.1016/j.jhydrol.2011.08.057

Prowse, T.D., Wrona, F.J., Reist, J.D., Gibson, J.J., Hobbie, J.E., Levesque, L.M., Vincent, W.F., 2006. Climate change effects on hydroecology of Arctic freshwater ecosystems. AMBIO: A J. Hum. Environ. 35(7), 347-359. https://doi.org/10.1579/0044-7447(2006)35[347:CCEOHO]2.0.CO;2 
Rasouli, K., 2017. Sensitivity Analysis of Mountain Hydrology to Changing Climate. Ph.D. thesis. University of Saskatchewan, Saskatoon, Canada. Pp. 251. https://harvest.usask.ca/handle/10388/7799

Rasouli, K., Pomeroy, J.W., Janowicz, J.R., Carey, S.K., Williams, T.J., 2014. Hydrological sensitivity of a northern mountain basin to climate change. Hydrol. Process. 28, 4191-4208. https://doi.org/10.1002/hyp.10244

Rasouli, K., Pomeroy, J.W., Marks, D.G., 2015. Snowpack sensitivity to perturbed climate in a cool midlatitude mountain catchment. Hydrol. Process. 29, 3925-3940. https://doi.org/10.1002/hyp.10587

Rasouli, K., Pomeroy J.W., and Whitfield P.H., 2019a. Hydrological responses of headwater basins to monthly perturbed climate in the North American Cordillera. J. Hydrometeorol. 20, 863-882. https://doi.org/10.1175/JHM-D-18-0166.1

Rasouli, K., Pomeroy, J.W., and Whitfield, P.H., 2019b. Are the effects of vegetation and soil changes as important as climate change impacts on hydrological processes? Hydrol. Earth Syst. Sci. 23, 4933-4954. https://doi.org/10.5194/hess-23-4933-2019

Rasouli, K., Pomeroy, J.W., Janowicz, J.R., Williams, T.J. and Carey, S.K., 2019c. A long-term hydrometeorological dataset (1993-2014) of a northern mountain basin: Wolf Creek Research Basin, Yukon Territory, Canada. Earth Syst. Sci. Data 11(1), 89-100. https://doi.org/10.5194/essd-11-89-2019

Rasouli, K., Scharold, K., Mahmood, T.H., Glenn, N.F., Marks, D., 2020. Linking hydrological variations at local scales to regional climate teleconnection patterns. Hydrol. Process. 34(26), 5624-5641. https://doi.org/10.1002/hyp.13982

Reba, M.L., Marks, D., Seyfried, M., Winstral, A., Kumar, M., Flerchinger, G., 2011. A long-term data set for hydrologic modeling in a snow-dominated mountain catchment. Water Resour. Res. 47(7). https://doi.org/10.1029/2010WR010030

Roche, J.W., Bales, R.C., Rice, R., Marks, D.G., 2018. Management Implications of Snowpack Sensitivity to Temperature and Atmospheric Moisture Changes in Yosemite National Park, CA. J. Am. Water Resour. Assoc. 54, 724-741. https://doi.org/10.1111/1752-1688.12647

Semadeni-Davies, A., Hernebring, C., Svensson, G., Gustafsson, L.G., 2008. The impacts of climate change and urbanisation on drainage in Helsingborg, Sweden: Combined sewer system. J. Hydrol. 350, 100-113. https://doi.org/10.1016/j.jhydrol.2007.05.028

Semmens, K., Ramage, J., 2013. Recent changes in spring snowmelt timing in the Yukon River basin detected by passive microwave satellite data. The Cryosphere 7, 905-916. https://doi.org/10.5194/tc-7-905-2013

Sospedra-Alfonso, R., Melton, J.R., Merryfield, W.J., 2015. Effects of temperature and precipitation on snowpack variability in the Central Rocky Mountains as a function of elevation. Geophys. Res. Lett. 42(11), 4429-4438. https://doi.org/10.1002/2015GL063898

Sproles, E., Nolin, A., Rittger, K., Painter, T., 2013. Climate change impacts on maritime mountain snowpack in the Oregon Cascades. Hydrol. Earth Syst. Sci. 17, 2581-2597. https://doi.org/10.5194/hess17-2581-2013

Stewart, I.T., Cayan, D.R., Dettinger, M.D., 2004. Changes in snowmelt runoff timing in western North America under a "business as usual" climate change scenario. Clim. Change. 62, 217-232. https://doi.org/10.1023/B:CLIM.0000013702.22656.e8

Stockton, C.W., Boggess, W.R., 1979. Geohydrological implications of climate change on water resource development. Technical Report. DTIC Document. Pp. 206. http://hdl.handle.net/10150/303803

Sultana, R., Choi, M., 2018. Sensitivity of Streamflow Response in the Snow-Dominated Sierra Nevada Watershed Using Projected CMIP5 Data. J. Hydrol. Eng. 23, 05018015. https://doi.org/10.1061/(ASCE)HE.1943-5584.0001640 
Sunyer, M., Madsen, H., Ang, P., 2012. A comparison of different regional climate models and statistical downscaling methods for extreme rainfall estimation under climate change. Atmos. Res. 103, 119-128. https://doi.org/10.1016/j.atmosres.2011.06.011

Viviroli, D., Weingartner, R., 2004. The hydrological significance of mountains: from regional to global scale. Hydrol. Earth Syst. Sci. 8(6), 1016-1029. https://doi.org/10.7892/boris.134006

Whitfield, P.H., Shook, K.R., 2020. Changes to rainfall, snowfall, and runoff events during the autumnwinter transition in the Rocky Mountains of North America. Can. Water Resour. J. 45(1), $28-42$. https://doi.org/10.1080/07011784.2019.1685910

Wilby, R.L., Hay, L.E., Gutowski, W.J., Arritt, R.W., Takle, E.S., Pan, Z., Leavesley, G.H. Clark, M.P., 2000. Hydrological responses to dynamically and statistically downscaled climate model output. Geophys. Res. Lett. 27(8), 1199-1202. https://doi.org/10.1029/1999GL006078

Wilby, R.L., Wigley, T., 1997. Downscaling general circulation model output: a review of methods and limitations. Prog. Phys. Geogr. 21, 530-548. https://doi.org/10.1177/030913339702100403

Williams, T.J., Pomeroy, J.W., Janowicz, J.R., Carey, S.K., Rasouli, K., Quinton, W.L., 2015. A radiativeconductive-convective approach to calculate thaw season ground surface temperatures for modelling frost table dynamics. Hydrol. Process. 29(18), 3954-3965. https://doi.org/10.1002/hyp.10573

Figures

\section{Hosted file}

image1.emf available at https://authorea.com/users/276226/articles/519853-the-sensitivityof-north-american-mountain-basin-snow-hydrology-to-changes-in-air-temperature-andprecipitation

Figure 1: Three headwater basins across the northern North American Cordillera: Wolf Creek, Yukon Territory; Marmot Creek, Alberta; and Reynolds Mountain East (Reynolds Mountain) catchment within Reynolds Creek Experimental Watershed, Idaho (USA). 

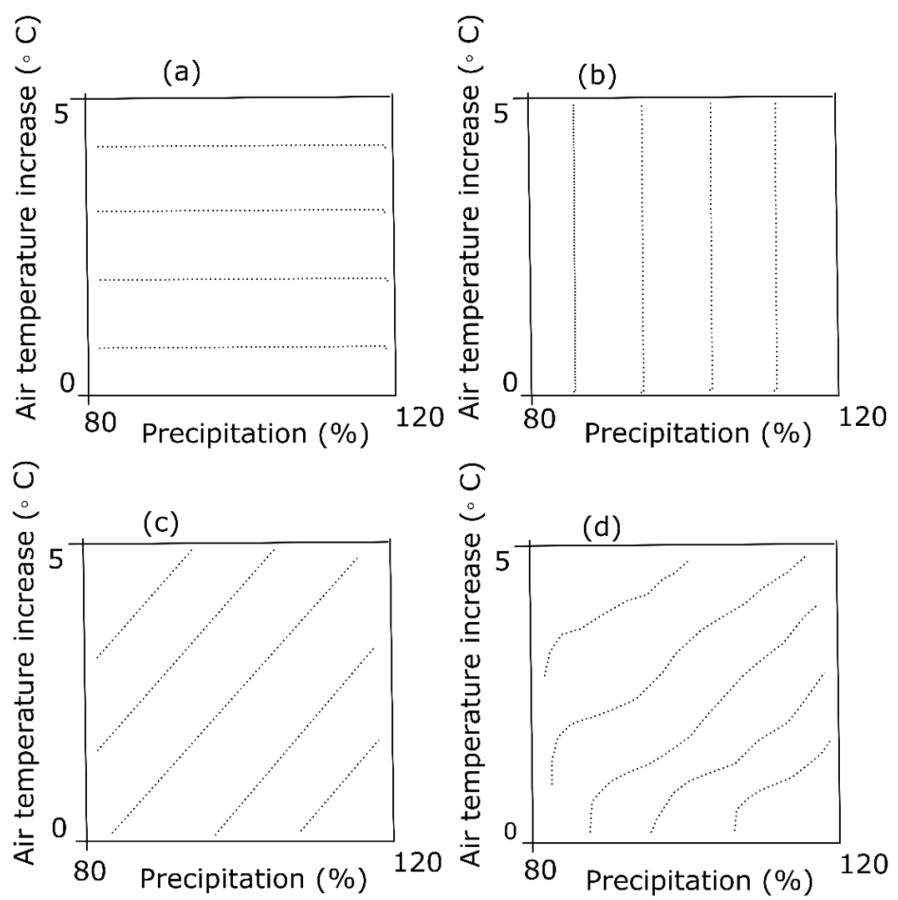

Figure 2: Guide to interpreting hydrological sensitivity to air temperature increase $\left(0^{\circ} \mathrm{C}\right.$ to $\left.5^{\circ} \mathrm{C}\right)$ and to changes in precipitation $(-20 \%$ to $+20 \%)$. The shape and slope of contours represent the sensitivity of a hydrological variable to a) air temperature increase, b) precipitation change, c) a linear interaction of air temperature and precipitation changes, and d) a complex interaction of air temperature and precipitation changes. 

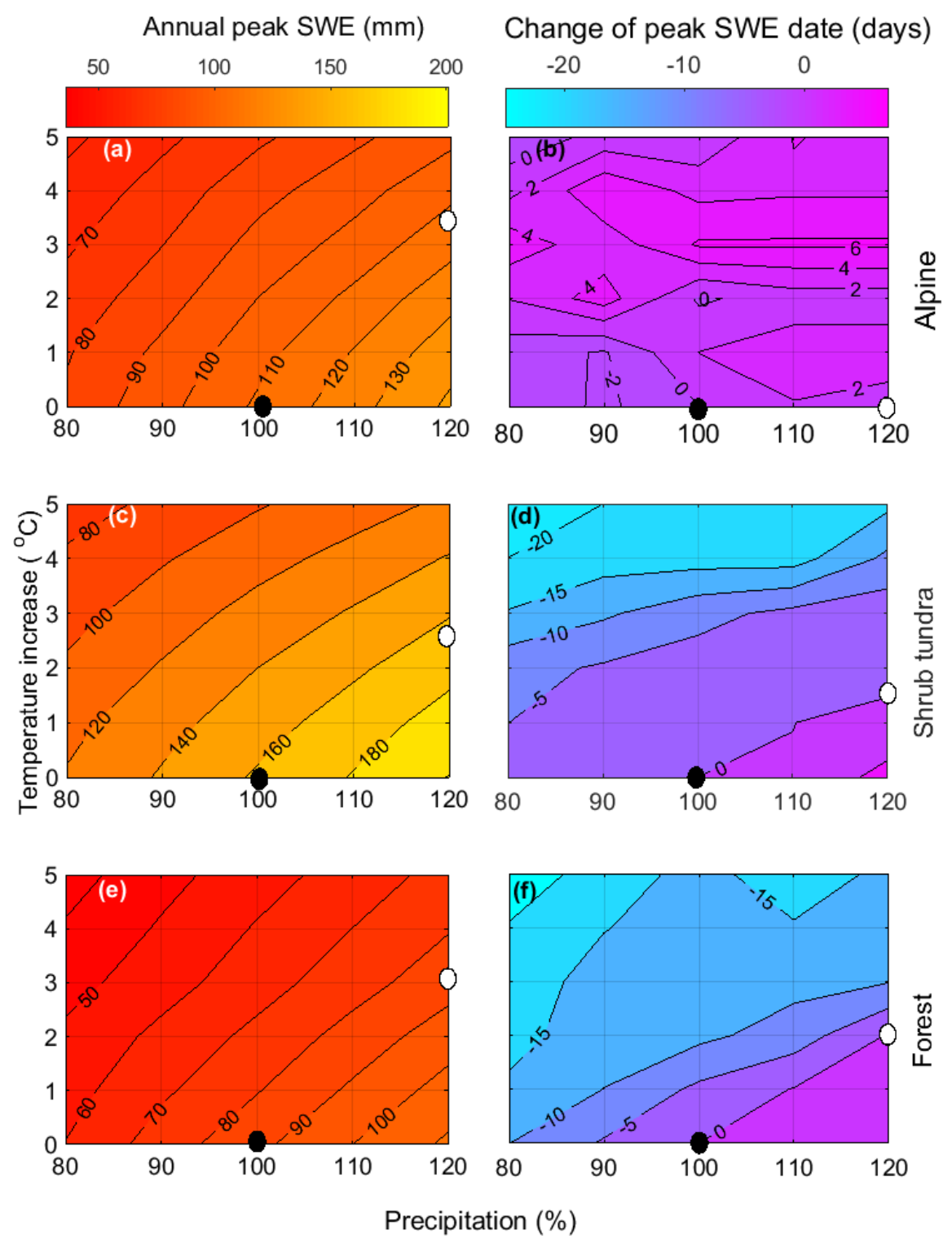

Figure 3: Sensitivity of mean annual peak SWE (left column) and timing of peak SWE (right column) in Wolf Creek with warming of $0^{\circ} \mathrm{C}$ to $5^{\circ} \mathrm{C}$ and changes in precipitation from -20 to $+20 \%$ in the three zones. The black dot indicates the present climate, and the white dot indicates the temperature increase that a $20 \%$ increase in precipitation can offset. 

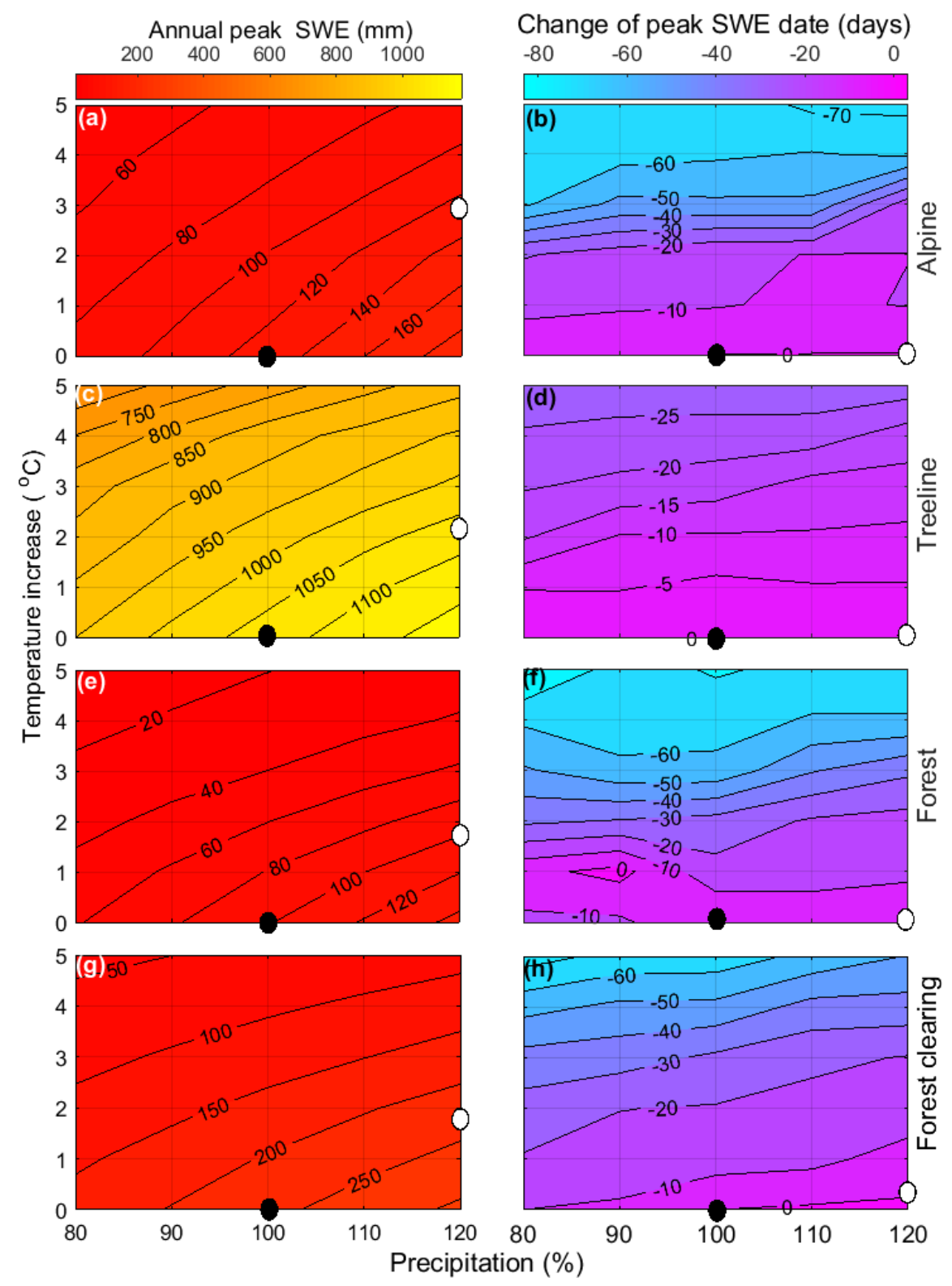

Figure 4: Sensitivity of mean annual peak SWE (left column) and timing of peak SWE (right column) in Marmot Creek with warming of $0^{\circ} \mathrm{C}$ to $5^{\circ} \mathrm{C}$ and changes in precipitation from -20 to $+20 \%$ in four zones. The black dot indicates the present climate, and the white dot indicates the temperature increase that a $20 \%$ increase in precipitation can offset. 

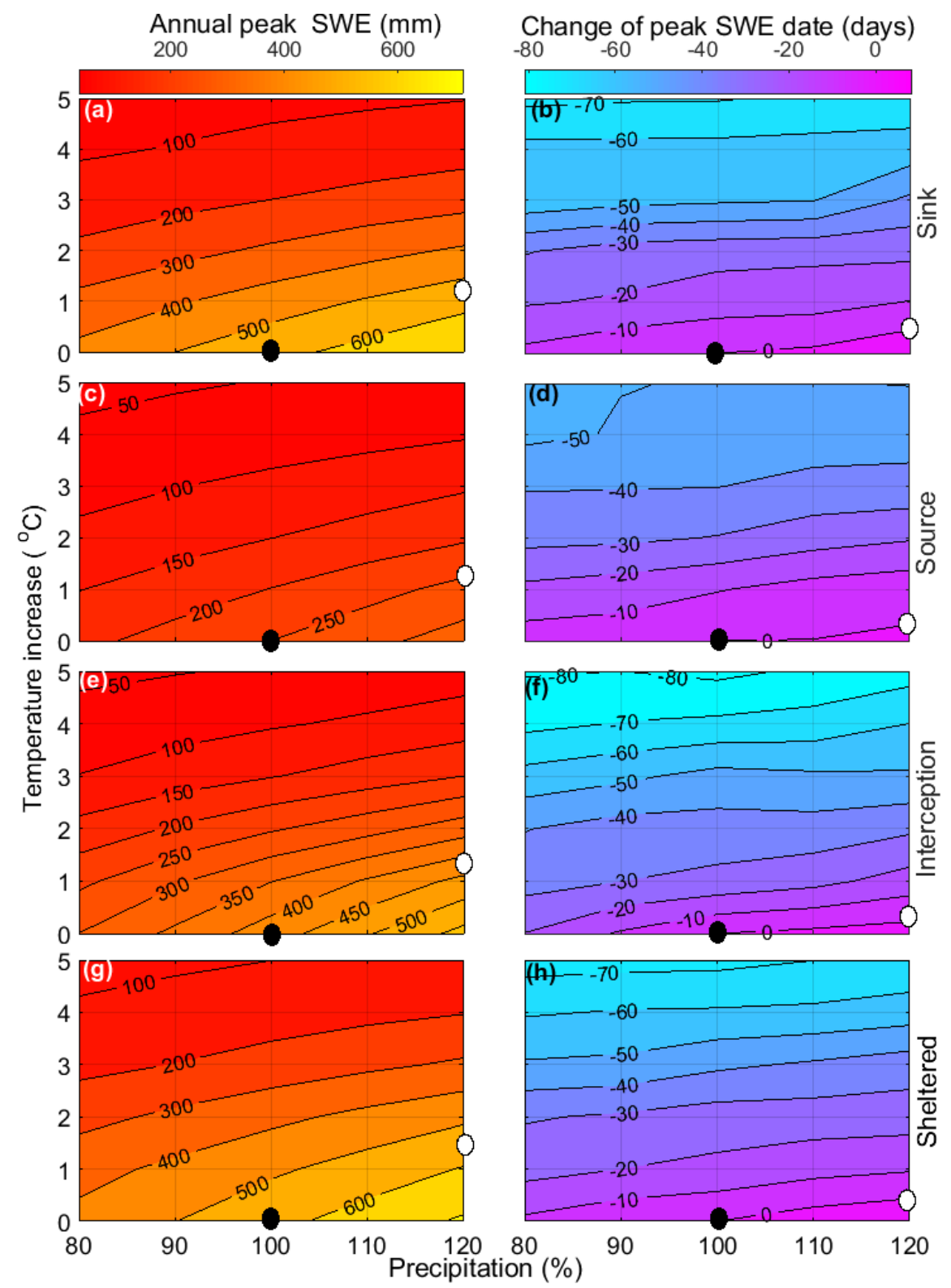

Figure 5: Sensitivity of mean annual peak SWE (left column) and timing of peak SWE (right column) in Reynolds Mountain with warming of $0^{\circ} \mathrm{C}$ to $5^{\circ} \mathrm{C}$ and changes in precipitation from -20 to $+20 \%$ in four zones. The black dot indicates the present climate, and the white dot indicates the temperature increase that a $20 \%$ increase in precipitation can offset. 

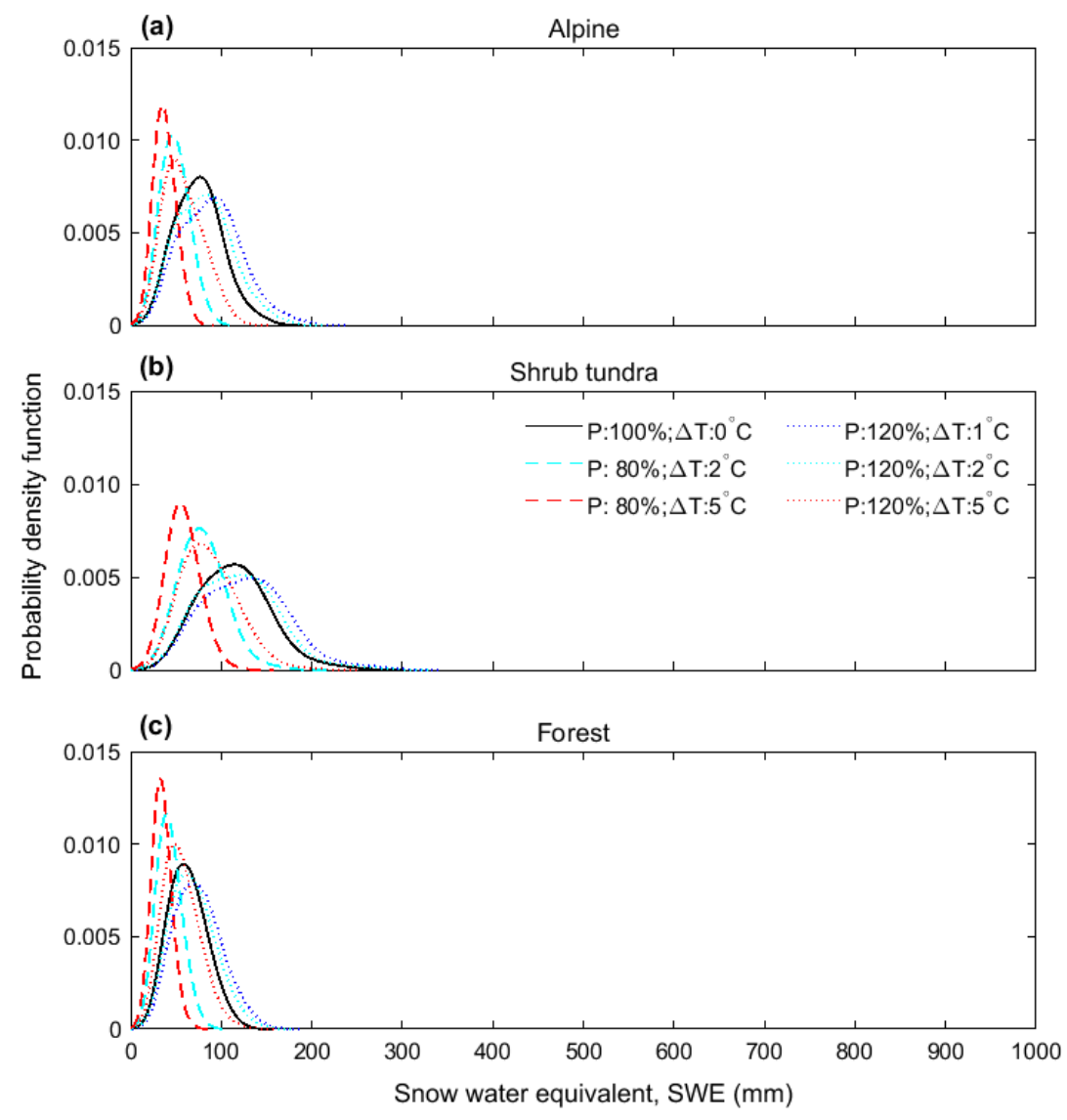

Figure 6: The probability distribution of snow water equivalent (SWE) in Wolf Creek with warming and precipitation change in each of the three zones from 18 years of hourly simulations. 


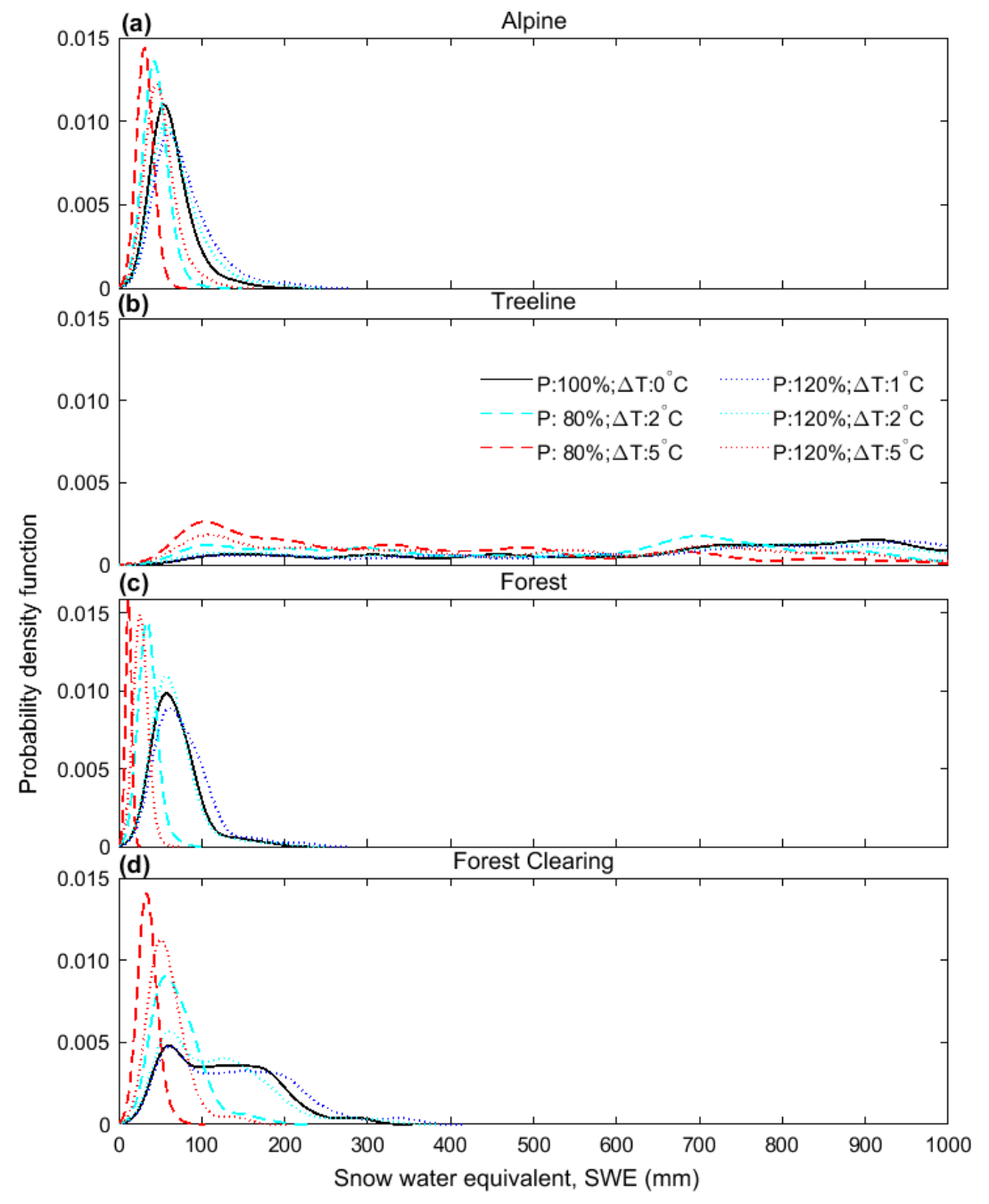

Figure 7: The probability distribution of snow water equivalent (SWE) in Marmot Creek with warming and precipitation change in each of the four zones from 9 years of hourly simulations. 


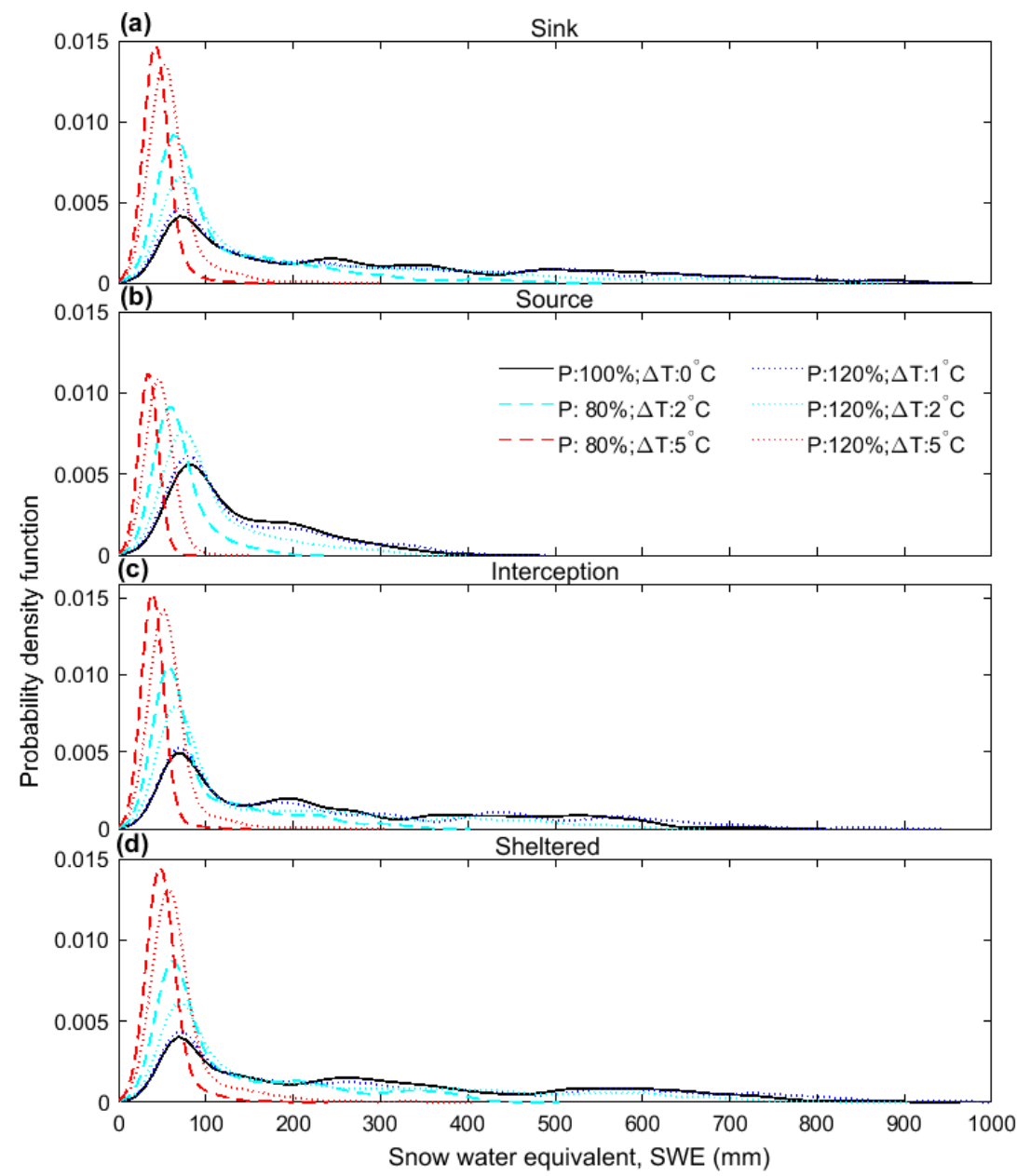

Figure 8: The probability distribution of snow water equivalent (SWE) in Reynolds Mountain with warming and precipitation change in each of the four zones from 25 years of hourly simulation. 


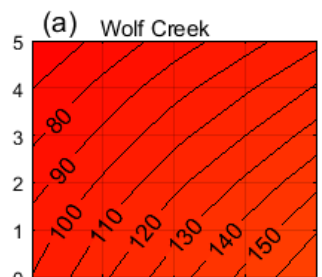

(b)

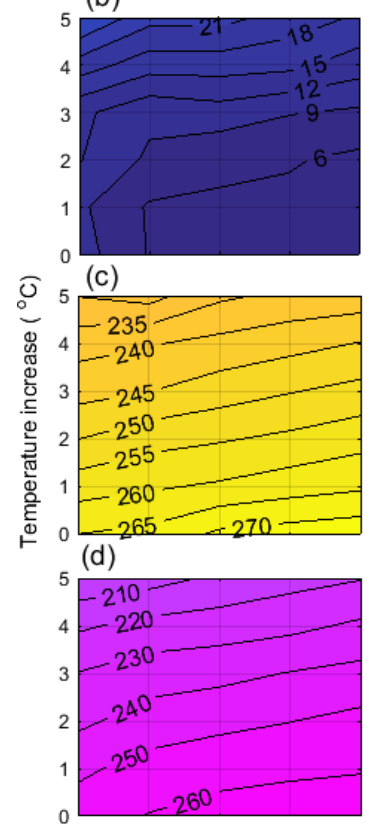

(e)

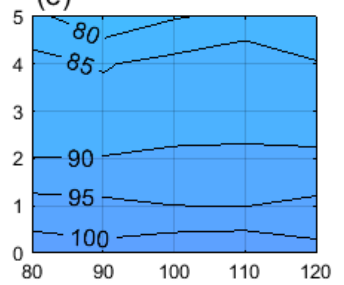

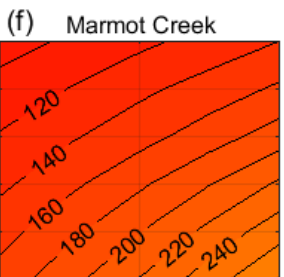

(g)

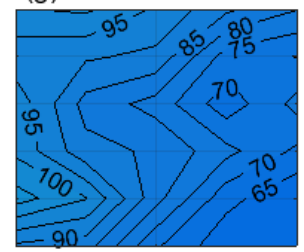

(h)

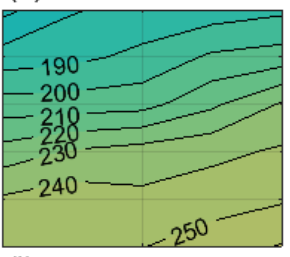

(i)

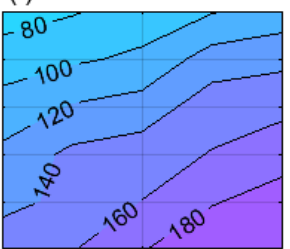

(j)

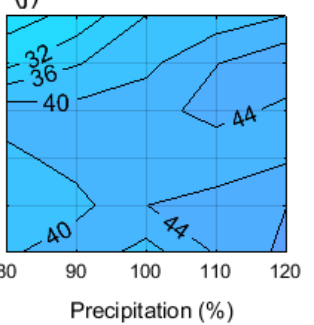

(k) Reynolds Mountain

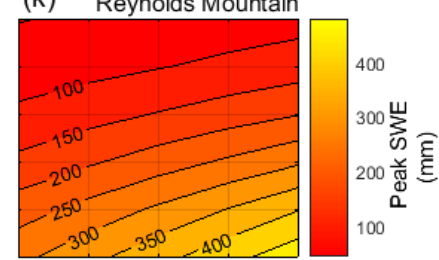

(I)

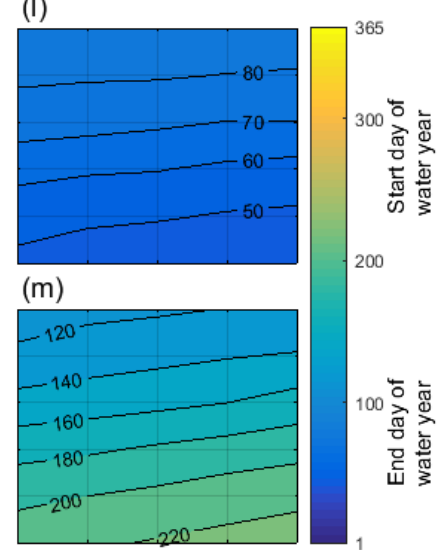

(n)

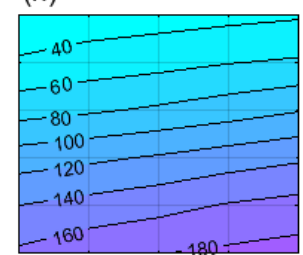

(o)

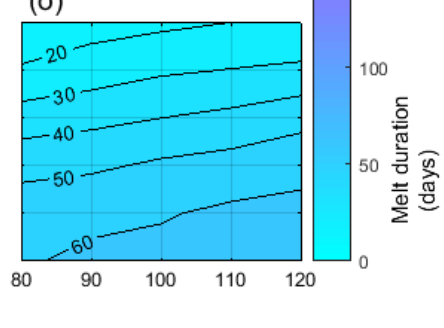

Figure 9: Magnitude and change of mean annual peak SWE, and the timing shift of the snow season start/end, snow season duration, and snowmelt period in the three basins with warming up to $5^{\circ} \mathrm{C}$ and precipitation change up to $\pm 20 \%$. Day of water year for the first day of each month are: 1:Oct, 32:Nov, 62:Dec, 93:Jan, 124:Feb, 152:Mar, 183:Apr, 213:May, 244:Jun, 274:Jul, 305:Aug, 336:Sep. 


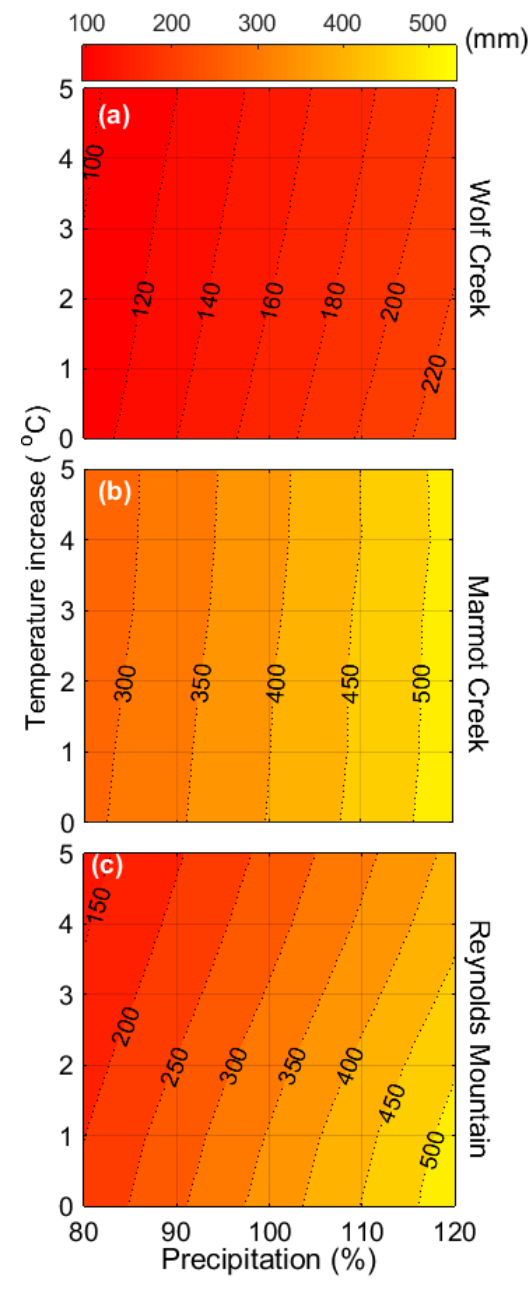

Figure 10: Sensitivity of mean annual runoff to increases in air temperature and changes in precipitation in (a) Wolf Creek at the Alaska Highway, (b) outlet of Marmot Creek, and (c) outlet of Reynolds Mountain. 


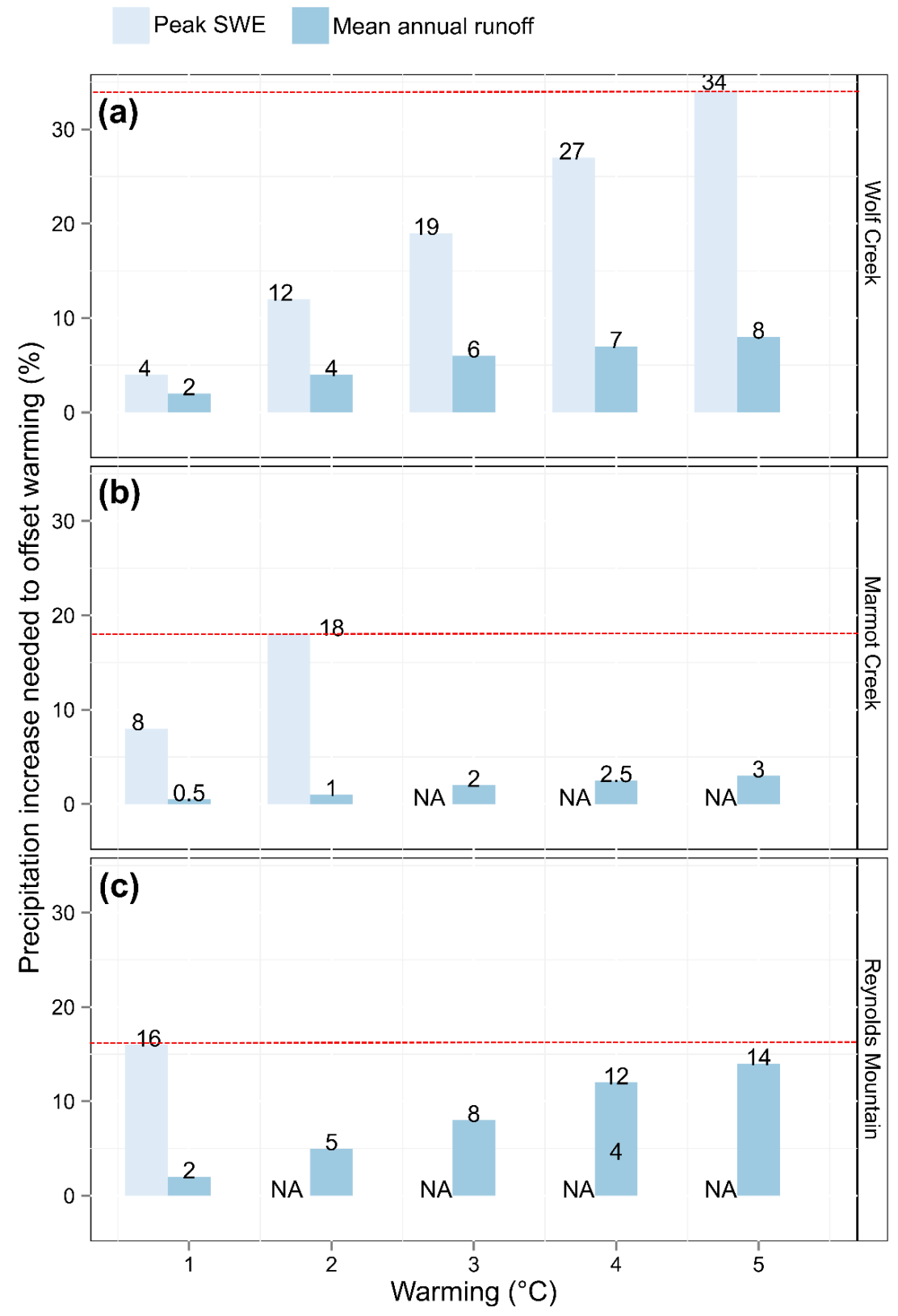

Figure 11: The percentage of precipitation change required to offset the effect of warming by $1-5^{\circ} \mathrm{C}$ on peak snow water equivalent (SWE) or mean annual runoff. NA is assigned to cases where the amount of precipitation required to offset the air temperature increase is greater than the increased precipitation projected by RCP scenarios and NARCCAP simulations (red horizontal lines) forced with the SRES A2 scenario (business-as-usual) for the period 2041-2070.

Tables:

Table 1: Sensitivity of snow and runoff regimes per $1^{\circ} \mathrm{C}$ warming in the three mountain basins. 


\begin{tabular}{lllll}
\hline & unit & Wolf Creek & Marmot Creek & Reynolds Mountain \\
\hline$\Delta$ Peak SWE & {$[\mathrm{mm}(\%)]$} & $-10(-8)$ & $-21(-10)$ & $-64(-17)$ \\
$\Delta$ Annual runoff & {$[\mathrm{mm}(\%)]$} & $-5(-3)$ & $-4(-1)$ & $-22(-6)$ \\
$\Delta$ Snow initiation & {$[$ day] } & 3 & 5 & 9 \\
$\Delta$ Peak SWE timing & {$[$ day] } & -3 & -13 & -12 \\
$\Delta$ Snow-free timing & {$[$ day $]$} & -7 & -13 & -21 \\
$\Delta$ Snowcover duration & {$[$ day] } & -11 & -18 & -30 \\
$\Delta$ Melt duration & {$[$ day] } & -5 & 0 & -9 \\
Simulation period & {$[$ year $]$} & 18 & 9 & 25 \\
\hline
\end{tabular}

Table 2: Sensitivity of the snow and runoff variables to warming and changes in precipitation in three mountain basins.

\begin{tabular}{|c|c|c|c|c|}
\hline Variable & No & warm & warm & warm \\
\hline & change & - & - & dry \\
\hline Warming $\left[{ }^{\circ} \mathrm{C}\right]$ & 0 & 2 & 5 & 5 \\
\hline Precipitation [\%] & 100 & 100 & 100 & 80 \\
\hline (1) Wolf Creek & (1) Wolf Creek & (1) Wolf Creek & (1) Wolf Creek & (1) Wolf Creek \\
\hline Peak SWE [mm] & 136 & 117 & 85 & 61 \\
\hline Annual runoff $[\mathrm{mm}]$ & 171 & 160 & 147 & 96 \\
\hline Initiation [date] & Oct 05 & Oct 07 & Oct 22 & Oct 27 \\
\hline Peak SWE [date] & Mar 16 & Mar 12 & Mar 03 & Feb 25 \\
\hline Snow-free [date] & Jun 28 & Jun 11 & May 22 & May 18 \\
\hline Snowcover duration [days] & 265 & 248 & 212 & 202 \\
\hline (2) Marmot Creek & (2) Marmot Creek & (2) Marmot Creek & (2) Marmot Creek & (2) Marmot Cre \\
\hline Peak SWE [mm] & 220 & 176 & 115 & 92 \\
\hline Annual runoff $[\mathrm{mm}]$ & 402 & 397 & 384 & 270 \\
\hline Initiation [date] & Dec 10 & Dec 23 & Jan 02 & Jan 08 \\
\hline Peak SWE [date] & Apr 30 & Apr 10 & Feb 24 & Feb 18 \\
\hline Snow-free [date] & Jun 07 & May 22 & Apr 01 & Mar 22 \\
\hline Snowcover duration [days] & 179 & 150 & 89 & 73 \\
\hline (3) Reynolds Mountain & (3) Reynolds Mountain & (3) Reynolds Mountain & (3) Reynolds Mountain & (3) Reynolds Mc \\
\hline Peak SWE $[\mathrm{mm}]$ & 390 & 222 & 63 & 47 \\
\hline Annual runoff $[\mathrm{mm}]$ & 371 & 331 & 263 & 161 \\
\hline Initiation [date] & Nov 11 & Nov 28 & Dec 25 & Dec 23 \\
\hline Peak SWE [date] & Mar 07 & Feb 08 & Jan 07 & Jan 04 \\
\hline Snow-free [date] & May 10 & Apr 02 & Jan 26 & Jan 19 \\
\hline Snowcover duration [days] & 180 & 125 & 32 & 27 \\
\hline
\end{tabular}

